\title{
Microhabitat Variability in Human Evolution
}

\author{
Robert Patalano ${ }^{1 *}$, Rebecca Hamilton ${ }^{1,2,3}$, Emma Finestone ${ }^{1}$, Noel Amano ${ }^{1}$, \\ Phoebe Heddell-Stevens ${ }^{1}$, Makarius Itambu ${ }^{1,4}$, Michael Petraglia ${ }^{1,5,6,7}$ and \\ Patrick Roberts ${ }^{1,5,8 *}$
}

\begin{abstract}
${ }^{1}$ Max Planck Institute for the Science of Human History, Jena, Germany, ${ }^{2}$ College of Asia and the Pacific, Australian National University, Canberra, ACT, Australia, ${ }^{3}$ Australian Research Council Centre of Excellence for Australian Biodiversity and Heritage, The Australian National University, Canberra, ACT, Australia, ${ }^{4}$ Department of Archaeology and Heritage Studies, University of Dar es Salaam, Dar es Salaam, Tanzania, ${ }^{5}$ School of Social Science, The University of Queensland, Brisbane, QLD, Australia, ${ }^{6}$ Department of Anthropology, National Museum of Natural History, Smithsonian Institution, Washington, DC, United States, ${ }^{7}$ Australian Research Centre for Human Evolution (ARCHE), Griffith University, Brisbane, QLD, Australia, ${ }^{8}$ Archaeological Studies Program, University of Philippines, Quenzon City, Philippines
\end{abstract}

\section{OPEN ACCESS}

Edited by:

Felix Riede,

Aarhus University, Denmark

Reviewed by: Jessica Thompson, Yale University, United States

Chenglong Deng, Institute of Geology and Geophysics (CAS), China

*Correspondence: Robert Patalano patalano@shh.mpg.de

Patrick Roberts roberts@shh.mpg.de

Specialty section:

This article was submitted to Quaternary Science, Geomorphology and Paleoenvironment, a section of the journal

Frontiers in Earth Science

Received: 01 October 2021 Accepted: 19 November 2021 Published: 06 December 2021

Citation: Patalano $R$, Hamilton $R$, Finestone $E$, Amano N, Heddell-Stevens $P$, Itambu $M$, Petraglia $M$ and Roberts $P$ (2021) Microhabitat Variability in Human Evolution.

Front. Earth Sci. 9:787669. doi: 10.3389/feart.2021.787669
Climate variability and hominin evolution are inextricably linked. Yet, hypotheses examining the impact of large-scale climate shifts on hominin landscape ecology are often constrained by proxy data coming from off-site lake and ocean cores and temporal offsets between paleoenvironmental and archaeological records. Additionally, landscape response data (most commonly, records of vegetation change), are often used as a climate proxy. This is problematic as it assumes that vegetation change signifies global or regional climate shifts without accounting for the known non-linear behavior of ecological systems and the often-significant spatial heterogeneity in habitat structure and response. The exploitation of diverse, rapidly changing habitats by Homo by at least two million years ago highlights that the ability to adapt to landscapes in flux had emerged by the time of our genus' African origin. To understand ecosystem response to climate variability, and hominin adaptations to environmental complexity and ecological diversity, we need cross-disciplinary datasets in direct association with stratified archaeological and fossil assemblages at a variety of temporal and spatial scales. In this article, we propose a microhabitat variability framework for understanding Homo's adaptability to fluctuating climates, environments, and resource bases. We argue that the exploitation of microhabitats, or unique ecologically and geographically defined areas within larger habitats and ecoregions, was a key skill that allowed Homo to adapt to multiple climates zones and ecoregions within and beyond Africa throughout the Pleistocene.

Keywords: microhabitat variability, human evolution, climate change, paleoecology, africa

\section{INTRODUCTION}

Climatic and environmental variability are often presented as major influencers on human evolution (Vrba, 1995b; Potts, 1998a; Trauth et al., 2010; Cerling et al., 2011; deMenocal, 2011), including the origins and diversification of Homo or the development of specific stone tool technologies (Potts et al., 2020; Lupien et al., 2021; Schaebitz et al., 2021). Variable Pliocene-Pleistocene climate for example, may have required hominins to effectively respond to the extreme selection pressures imposed by dynamic climatic systems, leading to genetic and morphological change and technological innovation (e.g., Committee on the Earth System Context for Hominin Evolution, 
2010). It is even argued that changes in African climate and hominin extinction, speciation, and behavioral events were inextricably linked over the past 6 million years (deMenocal, 2011). The last appearance of Australopithecus afarensis around 2.9 Ma (Campisano and Feibel, 2008; Alemseged et al., 2020), the appearance of the genus Homo at 2.8 Ma (Villmoare et al., 2015), the emergence of Paranthropus after 2.7 Ma (Coppens, 1968; Harrison, 2002), and the earliest evidence for Oldowan stone tools at 2.6 Ma (Semaw et al., 1997; Braun et al., 2019) appear to overlap with Northern Hemisphere glacial intensification, faunal changes, aridification, and grassland expansion in Africa (Bobe and Eck, 2001; Semaw, 2003; Evolution, 2010; deMenocal, 2011). Moreover, the emergence of Homo erectus and subsequent migrations out of Africa seemingly occurred when subtropical temperatures cooled around 1.9 Ma (Ravelo et al., 2004), while the appearance of the Acheulean at $\sim 1.75 \mathrm{Ma}$ has been suggested to coincide with increases in African wind-borne dust and aridification near 1.8 Ma (deMenocal, 2004; Lupien et al., 2018).

Yet, linking hominin landscape ecology and climate variability to technological, morphological, or behavioral changes remains challenging as clear cause-and-effect relationships between specific climatic events and major evolutionary occurrences are difficult to establish. This is often due to temporal and spatial gaps in paleoclimatic, paleoenvironmental, and archaeological records (Marean et al., 2015; Faith et al., 2019; Faith et al., 2021). Additionally, recent discoveries of the earliest stone tools (i.e., the Lomekwian) from Kenya dating to 3.3 Ma (Harmand et al., 2015), the earlier appearance of $H$. erectus in southern Africa at 2.0 Ma (Herries et al., 2020), and the likelihood that Acheulean biface shaping emerged gradually out of bifacial core reduction during the Oldowan (Duke et al., 2021) are not evidently linked with major climate and environmental events. Furthermore, Northern Hemisphere Glaciation was a gradual process, and a consistent stepwise transition toward greater aridity in Africa at $\sim 2.8 \mathrm{Ma}$ does not exist, with regional, often asynchronous, changes being observed in different parts of the continent (Trauth et al., 2021). Mammalian evolution is also not always directly linked to major climate shifts in a one-to-one manner as species adopt a variety of strategies, including mobility/migration, dietary, morphological, or cultural change, and the ongoing utilization of small microhabitats within a wider changing regional environmental context (Boutin and Lane, 2014; McCain and King, 2014; Figueirido et al., 2019; Stewart et al., 2021).

Indeed, particular caution must be adopted when studying paleoclimate and paleoecology within a human evolutionary framework, as hominin habitat-types are not always synchronous with changes in regional or global climate (Blumenthal et al., 2017; Groucutt, 2020; Faith et al., 2021; Trauth et al., 2021). That is, landscape response data (most commonly, records of vegetation change), are often used as a climate proxy even though it is well established that ecosystems do not necessarily exhibit a linear response to global or regional climate drivers (Holling, 1973; Bennett et al., 2021). Although difficult to identify archaeologically, we must also consider hominin agency, specifically the genus Homo in comparison to other hominins and primates, for its capacity to survive and adapt to resource limited conditions and manipulate their environments. We know, for instance, that by least $\sim 1.8 \mathrm{Ma}$ (Gabunia et al., 2000; Zhu et al., 2008; Garcia et al., 2010; Ferring et al., 2011) and possibly $2.1 \mathrm{Ma}$ (Zhu et al., 2018), Homo had adapted to multiple climate zones and ecoregions within and beyond Africa, selected specific habitats within larger biomes, and was able to tolerate extreme climatological and ecological events without the need of sophisticated technology. In addition, Middle Pleistocene hominins modified their ecosystems, such as through fire use, which influenced local and regional ecologies, thus adding another dimension to vegetation change that is not entirely climate mediated (Gowlett, 2016; Petraglia, 2017; Thompson et al., 2021).

Until relatively recently, cross-disciplinary datasets in direct association with stratified archaeological and fossil assemblages were not specifically targeted when reconstructing hominin landscape environments or ecologies. "Off-site" (i.e., distal) lake and ocean cores have produced well-integrated, highresolution reconstructions of the broad environmental context in which the genus Homo and its closest hominin relatives evolved, adapted, and experimented with novel technologies (Feakins et al., 2005; Feakins et al., 2007; Castañeda et al., 2009; Magill et al., 2013a; b; Uno KT. et al., 2016; Tierney et al., 2017; Caley et al., 2018; Colcord et al., 2018; Lupien et al., 2018; Lupien et al., 2019; Lupien et al., 2020; Lupien et al., 2021). These data, however, are often derived from sources distal to hominin activity. Although we have longterm records that demonstrate changes in plant landscape composition (Feakins et al., 2005; Feakins et al., 2007; Feakins et al., 2013; Uno K. T. et al., 2016), they do not necessarily show the ecological subtleties and complexity that on-site (i.e., proximal) records can provide. Increasingly, however, phytolith and pollen records (Bonnefille, 1995; Barboni et al., 1999; Albert et al., 2006; Bamford et al., 2006; Bamford et al., 2008; Albert et al., 2009; Barboni et al., 2010; Rossouw and Scott, 2011; Albert and Bamford, 2012; Barboni, 2014; Albert et al., 2018; Itambu, 2019; Mercader et al., 2021; Stollhofen et al., 2021), as well as paleontological and stable isotope analyses (WoldeGabriel et al., 1994; Cerling et al., 1997; Pickford and Senut, 2001; Wynn, 2001; White et al., 2009b; WoldeGabriel et al., 2009; Prassack, 2010; Cerling et al., 2011; Kovarovic et al., 2013; Magill et al., 2013a; b; Quinn et al., 2013; Bibi and Kiessling, 2015; Bibi et al., 2018; Colcord et al., 2018; Pante and de la Torre, 2018; Prassack et al., 2018; Faith et al., 2019; Roberts et al., 2020; Sanders, 2020), have sought to track changes in landscapes occupied by Pleistocene hominins. The pursuit of more detailed data relating to hominin population resource use and microhabitat availability across space and time is beginning to provide more nuanced insights into the relationship between hominin morphologies and technologies and local-to-regional scale environmental change (Barboni et al., 2010; Blumenschine et al., 2012; Magill et al., 2015; Itambu, 2019; Patalano, 2019; Martin et al., 2021; Mercader et al., 2021).

This article reviews the potential role of microhabitat variability in human evolution by examining archaeological and paleoecological datasets that have revealed hominin morphological and technological adaptations to changing 


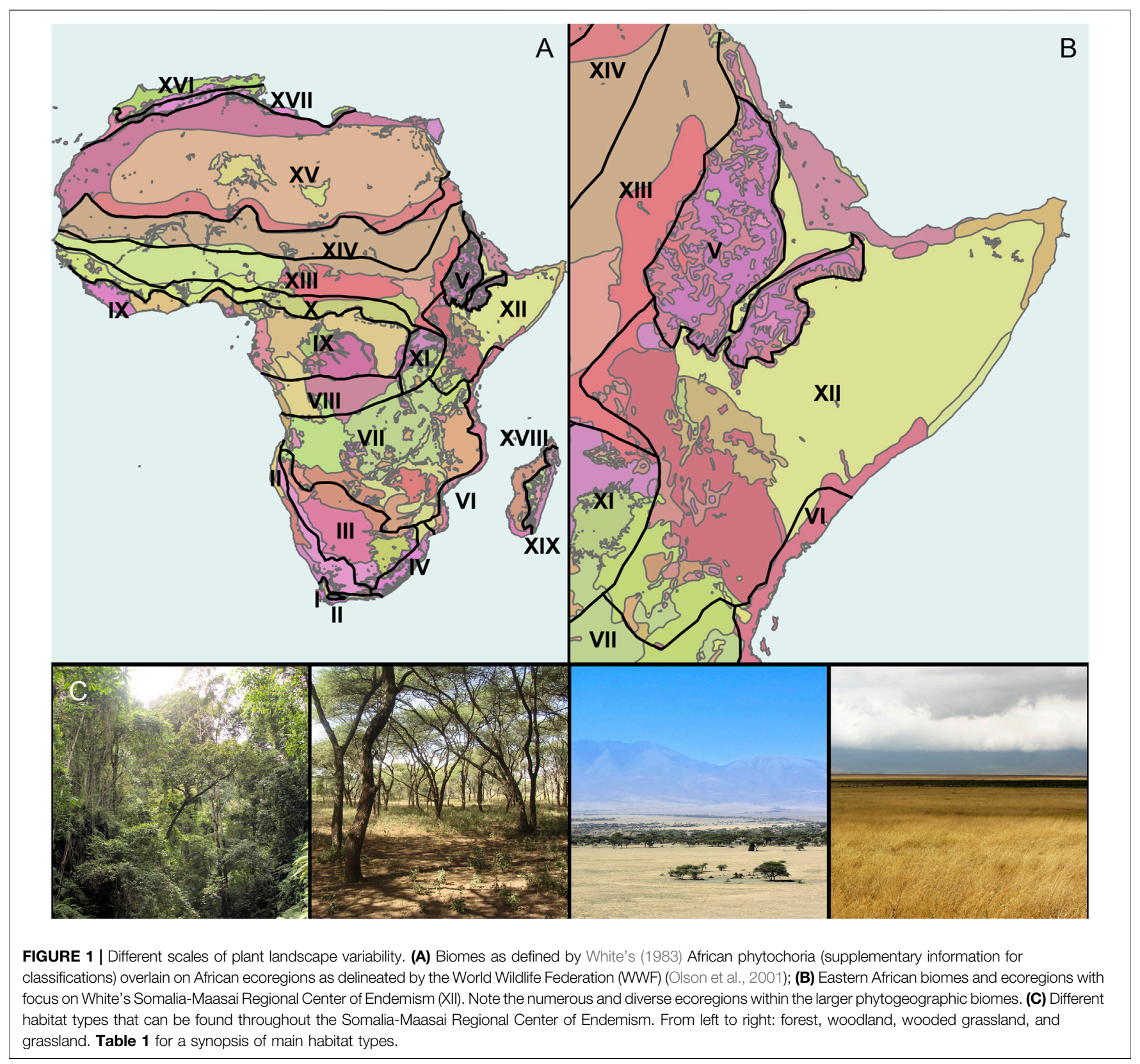

environments over time and space. We begin by defining microhabitat variability, and the differences between biomes, ecoregions, and habitats. We then present field and analytical research methods designed to identify microhabitat variability in the Pleistocene. This is followed by a review of the key prevailing climate and environmental hypotheses for human evolution, as well as issues related to landscape response data like the inherently non-linear attributes of some ecosystems. This is followed by case studies using three examples of microhabitat variability from Oldupai Gorge (formerly Olduvai) in Tanzania and the adaptability of Homo to distinct environmental settings. Finally, we propose a framework for utilizing diverse datasets compiled from multiple environmental proxy records as an analytical tool for evaluating hominin adaptability across ecologically diverse landscapes and consider how to best factor a microhabitat variability framework into existing paleoclimatic, paleoenvironmental, and evolutionary models.

\section{MICROHABITAT VARIABILITY}

High spatial resolution and multi-proxy archaeological and paleoecological datasets are crucial for locally reconstructing climate drivers and biome- and intrabiome-scale ecological change. Such analyses are a necessary starting point for underpinning how climate-ecosystem feedbacks have influenced hominin evolution. We classify "microhabitats" as unique ecologically and geographically defined areas within larger 


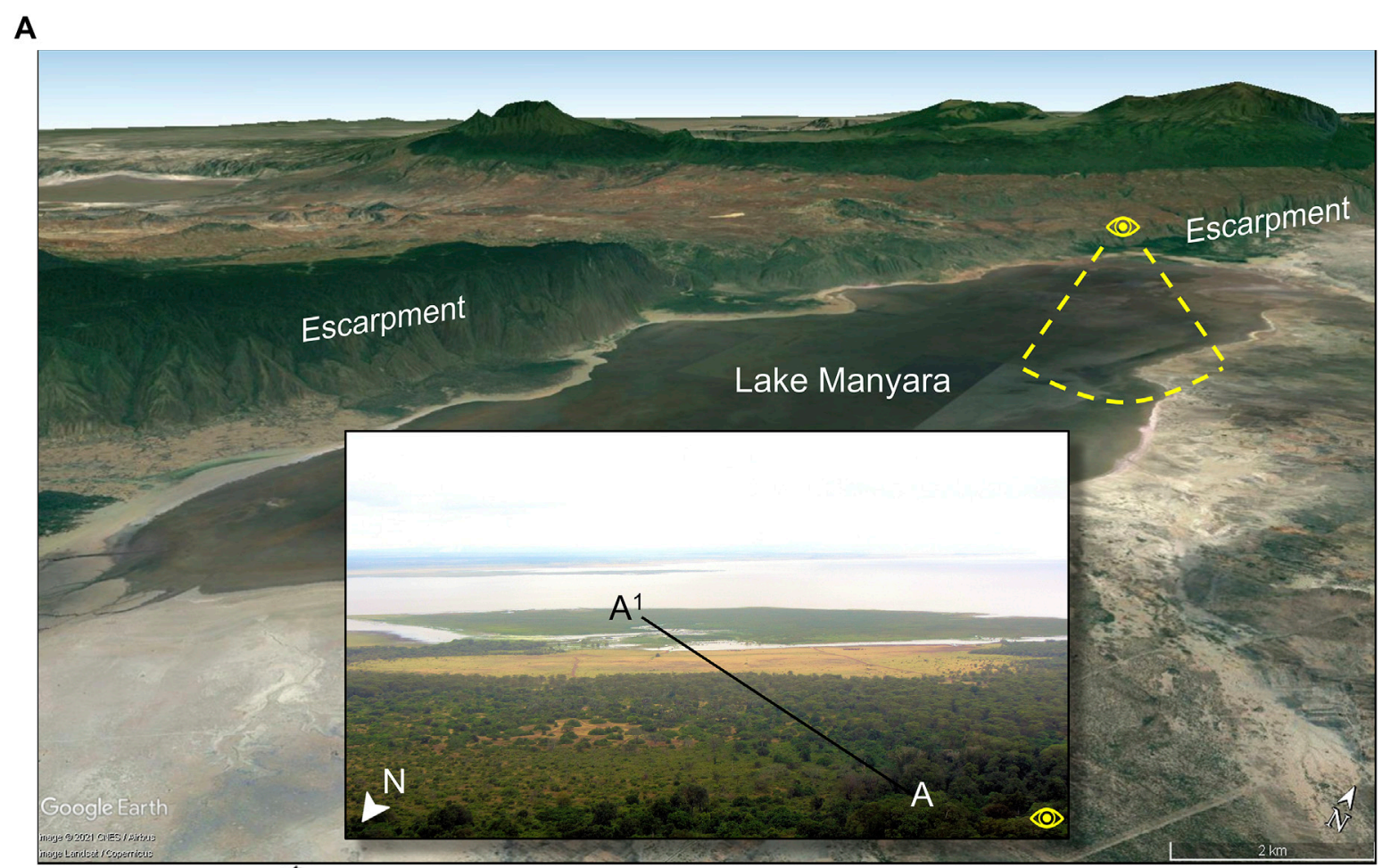

B

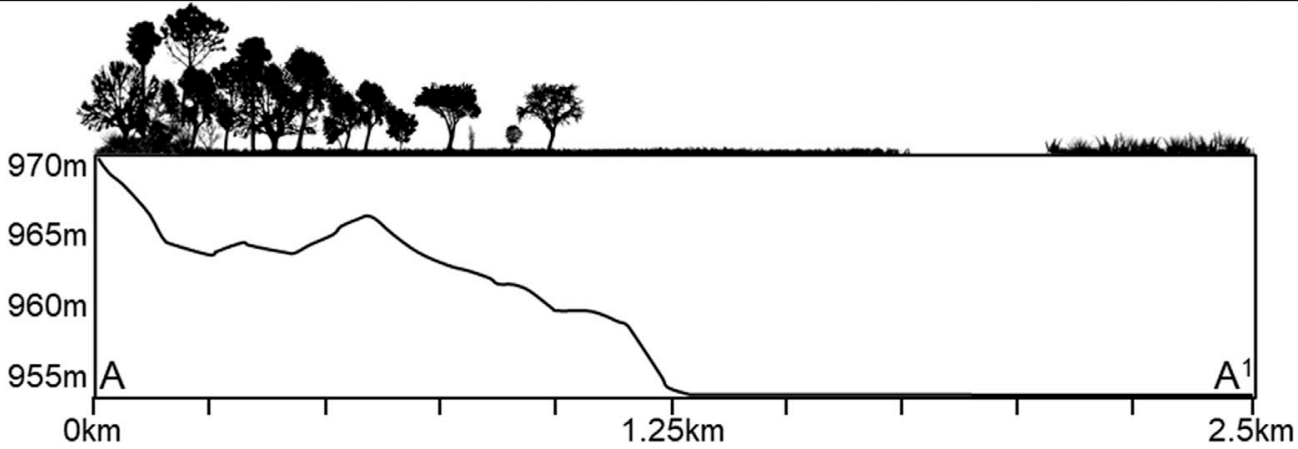

FIGURE 2 | (A) Google Earth image showing Lake Manyara in the Tanzanian Rift Valley and forests on the northern and western shores that are fed by groundwater discharged from the escarpment. Insert photo shows the view from atop the northern escarpment. (B) An ecological and elevation profile of segment $A-A^{1}$ showing variability at a small scale. In the ecological profile, true forest is found from 0 to $0.25 \mathrm{~km}$, and then gradually transitions to woodland until $\sim 0.6 \mathrm{~km}$ before opening into wooded grassland until $1.0 \mathrm{~km}$. After $1.0 \mathrm{~km}$, the wooded grassland transitions to an open grassland, which terminates at the water's edge at $1.75 \mathrm{~km}$. After $2.1 \mathrm{~km}$, emergent halophytic vegetation (saline and brackish swamp adapted species) flourish on an exposed surface.

habitats (Figure 1, Figure 2). At the largest scale are "biomes," which we identify using White's (1983) description of extant African phytochoria, termed Regional Centers of Endemism (White, 1979). Nested within the biomes are various "ecoregions," or relatively large areas of land containing a distinct assemblage of natural communities and species that share climatic and environmental conditions (Olson et al., 2001). The porosity and chemistry of soils, topography, groundwater sources, and edaphic conditions influence vegetation structure and floristic patterns to create distinct habitat and microhabitat assemblages inside each ecoregion (Sept, 2013). "Habitats" are areas covered by relatively uniform vegetation types within each ecoregion (Table 1), that represent major biotic zones and correlate with various climatic indices such as rainfall seasonality, summer aridity, and minimum winter temperatures (Van Wyk and Smith, 2001). A "microhabitat" on the other hand, is a smaller but highly distinctive area that differs from encompassing habitat types in that it exhibits unique floristic conditions that can change at meter scales (Figure 2). While, on a spatial scale, these ecosystems might seem relatively unimportant, biotically they can be home to a variety of diverse flora and fauna, often exerting specific pressures on the evolution of morphology, feeding behaviors, and migratory patterns (Fjeldså and Lovett, 1997; Stewart et al., 2010; Sintayehu, 2018).

Microhabitat variability is exemplified best by mosaics, or where local geological, tectonic, microclimatic, and hydrological conditions and both natural and anthropogenic 
TABLE 1 | Synopsis of main habitat types mentioned in the text. Adopted from White, 1983.

\begin{tabular}{|c|c|}
\hline & - \\
\hline Forest & $\begin{array}{l}\text { A continuous strand of trees at least } 10 \mathrm{~m} \text { tall with a closed, multistory, overlapping canopy. Woody plants dominate the } \\
\text { biomass, and a shrub layer is normally present. The ground layer is usually sparse but may contain bryophytes, epiphytes, } \\
\text { orchids, or mosses depending on moister availability }\end{array}$ \\
\hline Woodland & $\begin{array}{l}\text { Open stands of trees that are at least } 8 \mathrm{~m} \text { high, but no more than } 20 \mathrm{~m} \text {, with woody plants accounting for } 40 \% \text { of the } \\
\text { biomass over a field layer of grasses. Woodland canopies do not overlap extensively, but occasionally, stands of woodland } \\
\text { have a closed canopy and thus a poorly developed grass layer }\end{array}$ \\
\hline Bushland and thicket & $\begin{array}{l}\text { Open stands of bushes, defined as woody, multi-stemmed plants usually } 3-7 \mathrm{~m} \text { tall with a main stem } 10 \mathrm{~cm} \text { or more in } \\
\text { diameter, that cover }>40 \% \text { or more of the land. Bushes often flourish in rocky or stony substrates that are unfavorable to } \\
\text { grasses. Thicket is a closed stand of bushes that are so densely interlocked that they form a nearly impenetrable obstacle } \\
\text { that hinders movement }\end{array}$ \\
\hline Shrubland & $\begin{array}{l}\text { Stands of shrubs that vary in height from } 0.1 \text { to } 2 \mathrm{~m} \text {. Usually open or closed stands of shrubs occur where taller bushes and } \\
\text { trees cannot grow because of low rainfall, extended drought periods, low temperatures, high rates of evapotranspiration, } \\
\text { and oligotrophic or nutrient-poor soils }\end{array}$ \\
\hline Grassland & $\begin{array}{l}\text { Stretches of grasses and other herbs that develop when woody plant cover is }<10 \% \text {. African grasslands are structurally } \\
\text { simple with woody species only occurring in specialized microhabitats that are dependent on the availability of moisture. } \\
\text { Forbs also form an important component of grasslands and may contribute more in terms of biome species richness than do } \\
\text { grass species }\end{array}$ \\
\hline Wooded Grassland & $\begin{array}{l}\text { Stretches of grasses and other herbs, with woody plant cover ranging from } 10 \text { to } 40 \% \text {. Woody plants are always scattered, } \\
\text { but often grade into grassland or woodland }\end{array}$ \\
\hline
\end{tabular}

disturbances create well-defined patches of distinct plant communities that may offer unique food resources (Mucina and Rutherford, 2006). Gallery forests for example, are a key element within the Somalia-Maasai Regional Center of Endemism of eastern Africa (White, 1983), which consists of Acacia-Commiphora deciduous bushland and thicket, wooded grassland, edaphic grasslands, and other habitat types. Dense, fire-exclusionary gallery forests can grow proximal to abundant or permanent freshwater sources, including near rivers or groundwater aquifers. Thus, a particular combination of eco-hydrological conditions can permit the formation of highly diverse landscape mosaics over relatively small geographic distances (Mucina and Rutherford, 2006). Contributing to microhabitat variability is ecological diversity, which includes both alpha ( $\alpha$-diversity) and beta ( $\beta$-diversity) diversity (Whittaker, 1960). Alpha diversity reflects that within a localized microhabitat, while $\beta$-diversity reflects that between different microhabitat types. Both $\alpha$-diversity and $\beta$-diversity are determined by climatic conditions as well as the frequency of fires and other disturbances and a combination of slopes, aspect, soil depth and nutrients, moisture availability, age, and evolutionary history of the landscape (Geldenhuys, 1992; Mucina and Rutherford, 2006). The well-drained alluvial fans on the northwestern and western shores of Lake Manyara, Tanzania for example, support a "drought resilient" groundwater-fed evergreen forest that would otherwise not develop under the existing rainfall regime of $650 \mathrm{~mm}$ per year (Copeland, 2007; Barboni, 2014) (Figure 2). This forest is atypical of the Somalia-Maasai AcaciaCommiphora deciduous bushland and thicket and volcanic grasslands that abound in this region of Tanzania. Crucially, this forest supports key edible taxa that are relied upon by a range of fauna (such as chimpanzees in western Tanzania) like the Cape Mahogany (Trichilia emetica) and the Sycamore Fig (Ficus sycomorus) (Copeland, 2007 and references within).

\section{Identifying Microhabitat Variability}

Reconstructing microhabitat variability through archaeological or paleoecological proxies is, of course, difficult given the delimited nature of excavations or core retrieval and taphonomic limitations. Recent studies, however, have shown that it is possible to track microhabitat changes at spatial scales (Magill et al., 2015; Arráiz et al., 2017; Itambu, 2019; Patalano, 2019). Many archaeological and paleoanthropological sites permit well-defined, high-resolution temporal analyses, though few have had adjacent geological exposures that allow for analyses to be conducted at a high spatial resolution targeted as well. Oldupai Gorge in northern Tanzania, the Ain Béni MatharGuefait basin in eastern Morocco, and even the Nihewan Basin in northern China are such examples where exposed sedimentary deposits allow for radiometric or magnetostratigraphic dating of fluvio-lacustrine sequences so that both temporal and spatial paleo-reconstructions are possible (Figure 3). The application of sequence stratigraphic methods to geologic exposures provides a time-layered framework that enables correlations between sedimentary units across facies boundaries (Uribelarrea et al., 2017; Stanistreet et al., 2018). This also allows for the horizontal sampling of terrestrial sediments at and beyond archaeological sites, as well as across exposed sedimentary units along meter-, and when possible, kilometer-scale transects (Figure 3). The analyses of specific paleo-proxies (Table 2) collected in paleosol horizons can then help document spatial distributions in vegetation and provide an ecological context of such things as hominin foraging behavior or raw material procurement (Section 5).

Nevertheless, investigations into hominin resource use and microhabitat variability have largely been limited to Oldupai Gorge due to its number of documented archaeological sites, geographic extent, and well-defined stratigraphy (Barboni et al., 2010; Blumenschine et al., 2012; Magill et al., 2015; Itambu, 2019; Patalano, 2019; Mercader et al., 2021). Sampling at other paleoanthropological locations on the other hand, has mostly 


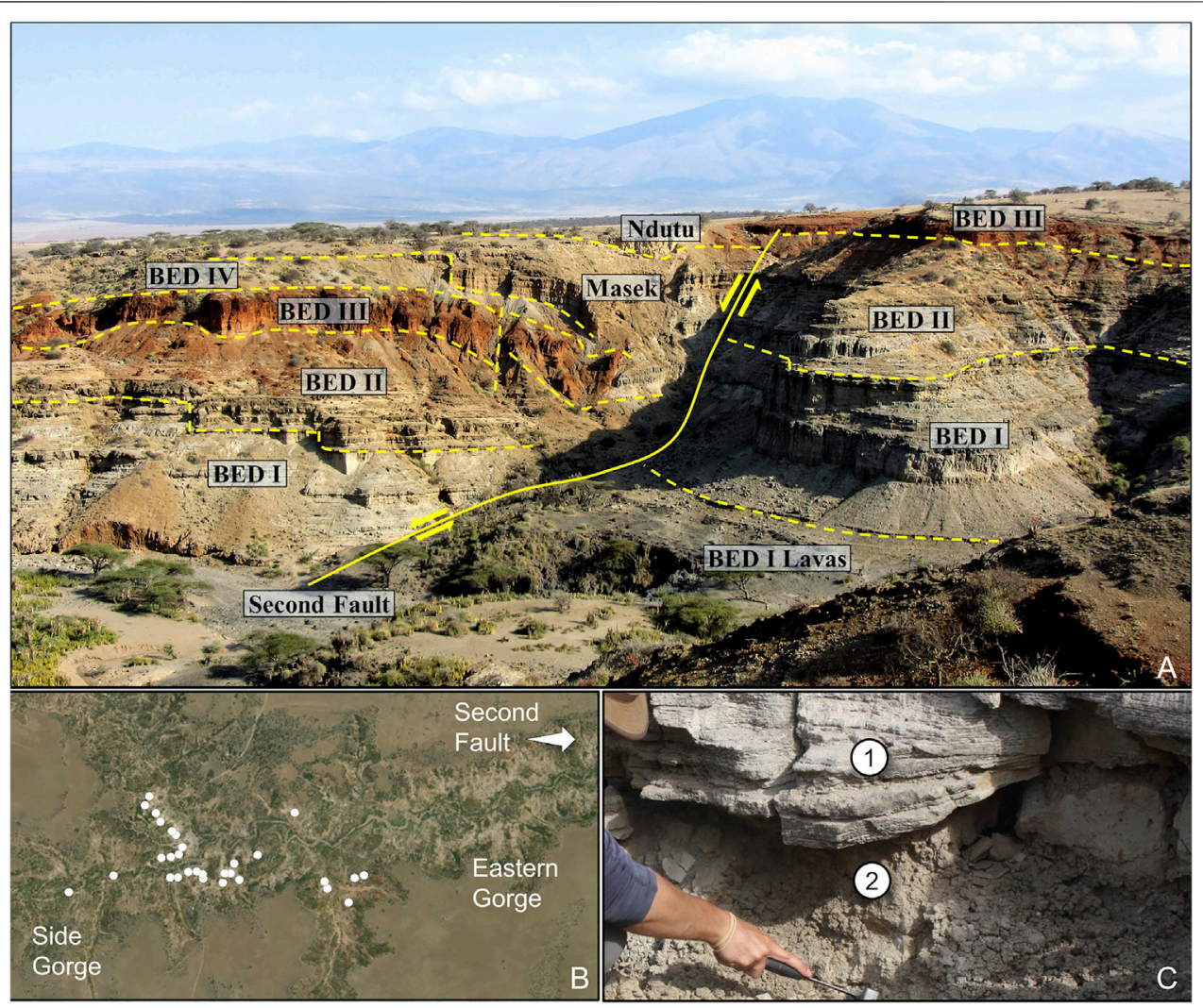

FIGURE 3 | Stratigraphic overview of Oldupai Gorge and landscape sampling for spatial habitat variability. (A) View of the Second Fault in the eastern part of the gorge and the displacement of the stratigraphic Beds. On the left (hanging wall), all beds except for Naisiusiu are exposed, while on the right (foot wall), only the Bed I Lavas and Beds I-III are visible. Exposure taken from the northern rim of the gorge facing south and encompasses $600 \mathrm{~m}$ east to west. Photo by Robert Patalano. (B) Locations (white dots) around the main confluence of the gorge where clays in contact below Tuff IF were sampled for plant wax biomarkers and phytoliths (Itambu, 2019; Patalano, 2019). (C) Example in which both Tuff IF (1) and the clays in contact below the tuff (2) are exposed. Photo by Laura Tucker.

TABLE 2 | Main paleoecological proxies that can be used to study microhabitat variability.

\begin{tabular}{|c|c|c|c|c|}
\hline & Pollen & Phytoliths & Plant waxes & Faunal isotopes \\
\hline Benefits & $\begin{array}{l}\text { Compositionally rich record of vegetation } \\
\text { change } \\
\text { Highest taxonomic resolution }\end{array}$ & $\begin{array}{l}\text { Often abundant in paleosols } \\
\text { Can track boundary between woodland and } \\
\text { grassland }\end{array}$ & $\begin{array}{l}\text { Ubiquitous in terrestrial and } \\
\text { aquatic sediments } \\
\text { Track photosynthetic pathway } \\
\text { and changes in hydroclimate }\end{array}$ & $\begin{array}{l}\text { Ratios track dietary } \\
\text { preference } \\
\text { Provide landscape-scale } \\
\text { environmental signals }\end{array}$ \\
\hline Drawbacks & $\begin{array}{l}\text { Preservation contingent on anoxic } \\
\text { conditions, usually in aquatic depositional } \\
\text { settings } \\
\text { Transport distance differs between taxa }\end{array}$ & $\begin{array}{l}\text { Cannot reliably identify photosynthetic } \\
\text { pathway or plant taxonomy, specifically at the } \\
\text { species level }\end{array}$ & $\begin{array}{l}\text { Production varies by taxonomic } \\
\text { group } \\
\text { Preservation depends on initial } \\
\text { burial dynamics and diagenesis }\end{array}$ & $\begin{array}{l}\text { Biased to feeding behavior } \\
\text { Not diagnostic of hominin } \\
\text { habitat preference }\end{array}$ \\
\hline
\end{tabular}

focused on proxy records collected in lake basin or ocean cores that track long-term climatic trends and regional environmental signals (Faith et al., 2021). Classifying paleo-microhabitats is also contingent on the taphonomy of environmental proxies (Table 2). Diverse faunal assemblages can suggest the juxtaposition of distinct microhabitats (Kovarovic et al., 2013), but can be skewed by niche exploitation of specific species by hominins or the disproportional preservation and dominance of some species [e.g., very large mammals $(\geq 180 \mathrm{~kg})$ ] in fauna collections over other [e.g., small mammals $(<1,000 \mathrm{~g})$ ] (Faith et al., 2019). Biogenic silica, pollen, and plant wax biomarkers (Godwin, 1934; Faegri and Iversen, 1989; Piperno, 2006; Sachse et al., 2012; Diefendorf and Freimuth, 2017; Cabanes, 2020; Patalano et al., 2021), are three additional proxies most often applied for plant landscape reconstructions (Table 2), and when used effectively, have the potential to produce a clear ecological context into which hominin behavior can be interpreted (e.g., Mercader et al., 2021). By taking a multi-proxy approach to studying non-analog ecosystems and microhabitat variability, it is possible to overcome some of the problems inherent with 
TABLE 3 | Synthesis of selected environmental hypotheses for human evolution.

\begin{tabular}{|c|c|c|c|c|c|}
\hline Hypothesis & Type & $\begin{array}{l}\text { Environmental } \\
\text { setting }\end{array}$ & Evolutionary outcome & Drawback & References \\
\hline Savanna & $\begin{array}{l}\text { Habitat } \\
\text { specific }\end{array}$ & $\begin{array}{l}\text { Transition from closed forest to } \\
\text { open grassland }\end{array}$ & $\begin{array}{l}\text { Bipedalism, tool use, } \\
\text { encephalization, etc. }\end{array}$ & $\begin{array}{l}\text { Hominin landscapes were ecologically } \\
\text { diverse with multiple habitat types }\end{array}$ & $\begin{array}{l}\text { Dart (1925); Washburn } \\
\text { (1960); Wilson (1979); } \\
\text { Wolpoff (1980) }\end{array}$ \\
\hline East side story & $\begin{array}{l}\text { Habitat } \\
\text { specific }\end{array}$ & $\begin{array}{l}\text { Wet, forested west/central } \\
\text { Africa vs. dry, open eastern } \\
\text { Africa }\end{array}$ & $\begin{array}{l}\text { Split between Pan and Homo from } \\
\text { last common ancestor }\end{array}$ & $\begin{array}{l}\text { Based on the assumption that hominin } \\
\text { evolution only occurred in eastern } \\
\text { Africa }\end{array}$ & Coppens (1994) \\
\hline Turnover pulse & $\begin{array}{l}\text { Climate } \\
\text { variability }\end{array}$ & $\begin{array}{l}\text { Rapid phases of aridity and } \\
\text { limited resources }\end{array}$ & Extinction and speciation & $\begin{array}{l}\text { No solid evidence for rapid ecological } \\
\text { and evolutionary changes in the } \\
\text { eastern African fossil record }\end{array}$ & $\begin{array}{l}\text { Vrba (1985); Vrba } \\
\text { (1995a); Vrba (1995b); } \\
\text { Vrba (2007) }\end{array}$ \\
\hline $\begin{array}{l}\text { Variability } \\
\text { selection }\end{array}$ & $\begin{array}{l}\text { Climate } \\
\text { variability }\end{array}$ & $\begin{array}{l}\text { Trends toward drier and more } \\
\text { variable climate resulting in } \\
\text { unpredictable resource base }\end{array}$ & $\begin{array}{l}\text { Heritable traits that enhance } \\
\text { adaptive versatility favored over } \\
\text { those that thrive in stable } \\
\text { environments }\end{array}$ & $\begin{array}{l}\text { Assumes linear driver-response } \\
\text { between climate change and hominin } \\
\text { ecosystem change }\end{array}$ & $\begin{array}{l}\text { Potts (1996); Potts } \\
\text { (1998b); Potts (2013) }\end{array}$ \\
\hline $\begin{array}{l}\text { Pulsed climate } \\
\text { variability }\end{array}$ & $\begin{array}{l}\text { Climate } \\
\text { variability }\end{array}$ & $\begin{array}{l}\text { Short periods of extreme } \\
\text { climate variability and rapid } \\
\text { landscape reorganization }\end{array}$ & $\begin{array}{l}\text { Hominin speciation, } \\
\text { encephalization, and dispersals } \\
\text { out of Africa }\end{array}$ & $\begin{array}{l}\text { Does not account for hominin localities } \\
\text { or habitats beyond the East African Rift } \\
\text { Valley }\end{array}$ & Maslin et al. (2014) \\
\hline Red queen & $\begin{array}{l}\text { Productive } \\
\text { stability }\end{array}$ & $\begin{array}{l}\text { Stable, predictable, resource } \\
\text { rich environments }\end{array}$ & $\begin{array}{l}\text { Competition amongst species } \\
\text { leading to fitness optimum and } \\
\text { evolution }\end{array}$ & $\begin{array}{l}\text { Ignores importance of abiotic factors } \\
\text { and may only operate at the } \\
\text { population level }\end{array}$ & Van Valen, (1973) \\
\hline $\begin{array}{l}\text { Chase red } \\
\text { queen }\end{array}$ & $\begin{array}{l}\text { Productive } \\
\text { stability }\end{array}$ & $\begin{array}{l}\text { Stable, predictable, resource } \\
\text { rich environments }\end{array}$ & $\begin{array}{l}\text { Cladogenesis (typically amongst } \\
\text { populations) }\end{array}$ & $\begin{array}{l}\text { Has been difficult to show in extinct } \\
\text { taxa }\end{array}$ & Strotz et al. (2018) \\
\hline $\begin{array}{l}\text { Microhabitat } \\
\text { variability }\end{array}$ & $\begin{array}{l}\text { Ecological } \\
\text { variability }\end{array}$ & $\begin{array}{l}\text { Diverse and varied with ample } \\
\text { resource opportunities }\end{array}$ & $\begin{array}{l}\text { Successful adaptability of Homo to } \\
\text { environmentally complex } \\
\text { landscapes }\end{array}$ & $\begin{array}{l}\text { Few paleoanthropological localities } \\
\text { allow for testing spatial variability }\end{array}$ & - \\
\hline
\end{tabular}

undertaking regional climate-ecosystem comparisons for human origins studies (Faith et al., 2019; Faith et al., 2021).

\section{ENVIRONMENTAL AND CLIMATE VARIABILITY AND HUMAN EVOLUTION}

The evolutionary significance of climatic and environmental variability has been reviewed elsewhere within the context of human origins (Vrba et al., 1989; Potts, 1996; 1998a; b; Vrba, 2007; Maslin and Trauth, 2009; Potts, 2013; Maslin et al., 2015; Faith et al., 2021). Early explanations of human evolution focused on intrinsic stimuli whereby a simple transition from one habitat type to another (forest to grassland, for example) set the stage for speciation or specific hominin characteristics like bipedalism and tool use (Dart, 1925; Washburn, 1960; Wilson, 1979; Wolpoff, 1980; Coppens, 1994). While these Habitat Specific Hypotheses have, for the most part, been replaced, their assumptions often persist in evolutionary discourse (Table 3). Generally, these hypotheses stipulate that the transition from closed woodlands to open grasslands underpinned the development of meat-eating, hunting, brain enlargement, fire use, food distribution, complex sociality, and even language (review in Potts, 2013).

Laporte and Zihlman (1983) were early proponents for the impact of environmental change on driving African mammalian evolution (including hominins) by proposing that adaptive changes were a response to changing environments caused by global cooling or orogeny, or as hominins migrated into new habitats. This has since resulted in multiple climate variability hypotheses that link changes in climate to environmental reorganization and subsequent speciation and extinction events, species' adaptive versatility, and the selection of behavioral and morphological mechanisms that enhance adaptive fitness (Table 3). For instance, the appearance of Homo and Paranthropus around $2.5 \mathrm{Ma}$ was proposed to have followed climate pulses caused by Northern Hemisphere glacial intensification and the closing of the Isthmus of Panama (Vrba et al., 1989; Vrba, 1995a; b). We now know, however, that there is even earlier evidence of Homo around $2.8 \mathrm{Ma}$ (Villmoare et al., 2015), and possibly as early as 3.3 Ma, (Püschel et al., 2021), and there was no pulse towards greater aridity in Africa at the time (Trauth et al., 2021). On the other hand, increased ecological resource variability (Potts et al., 2020) is considered a major factor in a species' adaptive versatility specifically in unstable, unpredictable, or unfamiliar environments, and there is now more compelling evidence for hominin evolutionary events during periods of highly variable eastern African climate shifting from very-dry and very-wet conditions between 5.0 and 0.2 Ma (Trauth et al., 2005; Maslin et al., 2013; Maslin et al., 2014; Potts et al., 2020; Lupien et al., 2021).

In contrast to these hypotheses centered on upheaval and change, some treatises have argued that climatic stability may have been important for driving hominin evolution as species must adapt and evolve in competition with other evolving species (Van Valen, 1973; Strotz et al., 2018). In these (Table 3), highly productive and stable environments lead to competition among species resulting in directional selection as they move toward fitness optimum when striving to gain a competitive advantage over others (Brockhurst et al., 2014). As cladogenesis can lead to populations deviating from their species and the possibility of a descendant evolving while its ancestor persists, there is thus a link between microevolutionary processes and macroevolutionary 
patterns (Strotz et al., 2018). P. boisei, H. erectus, H. habilis and $H$. rudolfensis were all present at Koobi Fora during the maximum extent of Paleo-Lake Lorenyang (1.9-1.8 Ma), when resource availability would have been highest, resulting in these hominins co-evolving in competition with each other (Maslin et al., 2015). Additionally, Au. sediba, $P$. robustus, and $H$. erectus were contemporaneous in South Africa between 2.04 and $1.95 \mathrm{Ma}$ (Berger et al., 2008; Herries et al., 2020), coinciding with substantial changes in South African ecosystems that may have placed selective pressures on Australopithecus, leading to divergent Homo and Paranthropus lineages (Ledogar et al., 2016; Joannes-Boyau et al., 2019).

\section{ECOSYSTEM RESILIENCE IN FACE OF CLIMATE CHANGE}

Disentangling the influence of climate changes on plant landscapes and impacts on resource availability is a fundamental, yet often overlooked, stepping-stone for linking climate drivers to human behavioral change, evolution, and migration patterns. This is an essential element for validation of the variability hypotheses given that they all mandate a degree of environmental determinism (e.g., Faith et al., 2021). Yet historically, paleoecological and paleoclimatic records have often been conflated (e.g., Morrison and Hamilton, 1974), an approach often necessitated by cost, access, and methodological constraints. While linear driver-response assumptions may be viable for climatically sensitive habitats such as tropical montane settings, they may overlook the inherently non-linear attributes of ecosystems (Holling, 1973; Hirota et al., 2011; Willis et al., 2013; Seddon, 2021). Thus, an interpretation of a stable climate exclusively drawing on paleoecological data extracted from a climatically resilient ecosystem would be entirely misconstrued (Hamilton et al., 2020). Equally problematic is an assumption of extreme climate change from ecological data showing a catastrophic ecological state shift in response to a relatively minor, potentially non-climatic disturbance (Hirota et al., 2011). This emphasizes the importance of producing independent records of climatic and non-climatic stressors and landscape response data prior to making interpretations of hominin behavior from the archaeological record.

From a climate perspective, the progressive formation of the East African Rift System (EARS) after $12 \mathrm{Ma}$ increased aridity in eastern Africa as wind patterns became less zonal, reducing available moisture particularly on the leeward sides of uplifted regions (Sepulchre et al., 2006; Hardt et al., 2015). Tectonic activity also helped create distinctive and topographically complex landscapes and geographical barriers that hominins had to successfully navigate (King and Bailey, 2006). Evidence from soil carbonates (Wynn, 2001; Levin et al., 2004; Wynn, 2004; Levin et al., 2011; Quade and Levin, 2013) and pollen and plant wax biomarkers (Feakins et al., 2005; Feakins et al., 2007; Feakins et al., 2013) illustrate a progressive proliferation of $\mathrm{C}_{4}$ plants beginning at approximately $10 \mathrm{Ma}$, presumably in response to increased aridity following rifting (deMenocal, 2004). Grass pollen and plant wax biomarkers from marine cores in the
Gulf of Aden (Feakins et al., 2013) and the Somali Basin (Uno $K$. T. et al., 2016) show that $C_{3}$ grasslands had actually expanded in eastern Africa by $12 \mathrm{Ma}$ but from $10 \mathrm{Ma}$ onwards, were steadily replaced by $\mathrm{C}_{4}$ plants (Feakins et al., 2007; Uno K. T. et al., 2016), though this was not a gradual process (Magill et al., 2013a; b; Colcord et al., 2018; Lupien et al., 2019).

Changes in northeastern African flora have also been attributed to variability in orbital precession (Feakins et al., 2005; Feakins et al., 2007; Maslin and Trauth, 2009; Magill et al., 2013b; Feakins et al., 2013; Uno KT. et al., 2016; Lupien et al., 2018). Precession, with an average periodicity of $\sim 23,000$ years, may have influenced human evolution and adaptability by controlling local water availability, biome diversification, and key speciation and dispersal events (Maslin and Trauth, 2009; Potts, 2013). Environmental variability may have also increased the adaptive versatility of hominins and their capacity to adjust to new habitats (Potts, 2013). The timing and nature of changes in hydrology and vegetation cover and the relationship to hominin species turnover (Feakins et al., 2007; Lupien et al., 2018), the appearance of new stone tool technologies (Lupien et al., 2020), the ability to control fire (Collins et al., 2017; Brittingham et al., 2019), and hominin dispersals out of Africa (Castañeda et al., 2009; Tierney et al., 2017) have all been viewed in light of orbital forcing and environmental variability. In southeastern Africa, rapidly fluctuating wet-dry cycles between approximately $2.2 \mathrm{Ma}$ to $2.0 \mathrm{Ma}$ likely contributed to the local extinction of Australopithecus and Paranthropus due to habitat marginalization (Caley et al., 2018), at a time when the genus Homo was emerging prominently in Africa (Antón, 2003; Plummer et al., 2009; Herries et al., 2020).

On shorter timescales, the Intertropical Convergence Zone (ITCZ) dictates the position of African and Indian Ocean Monsoons and controls the seasonal distribution of precipitation across Africa (Nicholson, 1996). Driven by solar insolation, the ITCZ produces singular rainy seasons in many parts of the continent, but it is difficult to simply attribute African precipitation cycles directly to incoming solar radiation (Yang et al., 2015), as African hydroclimate is modulated by influences from both the West African and Indian Ocean monsoons, the Walker Circulation, topography, and anomalies of ocean sea-surface temperatures, all of which can cause unimodal to trimodal distributions of rainfall across of the continent (Nicholson, 1993, 1996; Williams et al., 2012; Yang et al., 2015; Parhi et al., 2016; Ummenhofer et al., 2018; Schaebitz et al., 2021). In eastern Africa for example, the region's aridity has been attributed to the Turkana low-level jet (Nicholson, 2016) and orography (Christensen and Kanikicharla, 2013) even though there is a bimodal annual cycle of precipitation. Continental rainfall distribution is also sensitive to changes in the El Niño Southern Oscillation (ENSO) (Nicholson and Selato, 2000; Pausata et al., 2017), originating from Pacific sea surface temperature anomalies (Kaboth-Bahr et al., 2021). Changes in ENSO influence east-west and equatorial-southern moisture gradients across Africa (Nicholson and Selato, 2000; Nash et al., 2016; de Oliveira et al., 2018), such that when humid condition prevail in eastern or equatorial Africa, arid conditions persist in 
western or southern Africa (Nicholson, 1996; Kaboth-Bahr et al., 2021).

African plant landscapes, and forests in particular, are unique in that they recover faster after disturbances and appear to be more resistant to drought compared to other tropical habitats, such as those in South America or Southeast Asia (Willis et al., 2013; Cole et al., 2014; Bennett et al., 2021). This droughtresistance may be due to the relatively dry contemporary conditions across the continent (Malhi et al., 2004) as well as the biogeographic history and diversification of drought-adapted species (Parmentier et al., 2007). As African climate has oscillated between wetter and drier conditions, modern plant biomes may have developed drought-tolerance over time due to the loss of mesic-adapted species (Pennington et al., 2009). If, for example, humid lowland tropical African forests are more resistant to short-term extreme climate anomalies today, it is possible that moisture availability across Africa (e.g., paleo-ENSO effects) may not have had a large role in governing the distribution of vegetation communities or plant landscape structure at shorter timescales during the Pleistocene (Bennett et al., 2021). There is also non-linearity in both the spatial and temporal response of African vegetation to specific climatic drivers. Understanding these differences is important for determining spatial patterns of resilience and the sustainability of ecosystems in relation to climate changes (Willis et al., 2013).

Alternatively, hominin ecosystem engineering, especially intentional fire manipulation by $H$. sapiens, is an aspect of vegetation change that is not entirely climate mediated but may have had a significant influence on plant community composition and structure (Gowlett, 2016; Petraglia, 2017; Thompson et al., 2021). Controlled fire use is apparent in the archaeological record prior to the Middle Stone Age (Glikson, 2013; Gowlett, 2016), and both archaeological and ethnographic evidence indicate deliberate landscape modification through controlled burning to maintain mosaic landscapes and as a subsistence-related strategy (White, 2013; Scherjon et al., 2015; Petraglia, 2017; Bliege Bird et al., 2020; Thompson et al., 2021). This also suggests that controlled and manipulated fire may have had a pronounced effect on Pleistocene environments (Archibald et al., 2012), with Middle Pleistocene hominins burning landscapes to create resource-rich microhabitats that provided populations with abundant gatherable plants and ecological settings appealing to animal prey species (Haws, 2012; Thompson et al., 2021). Reconstructing paleoenvironments through a microhabitat variability framework can therefore help to understand the impact of hominin ecosystem modification on plant landscapes, especially when nonlinearity and spatial patterns of resilience and climate drivers are also considered.

\section{MICROHABITAT VARIABILITY AND HUMAN EVOLUTION}

By two million years ago, there is an apparent increase in the body mass of Homo (Pontzer, 2012; Antón et al., 2014), which in turn is related to its wider geographic distribution compared to other hominins (Antón, 2003) and an increase in energy expenditure (Aiello and Key, 2002; Aiello and Wells, 2002). Additionally, there was a shift in the archaeological record from assemblages of low-density artifact scatters in narrower depositional contexts to denser concentrations of archaeological material in a broader array of habitat settings (Plummer and Finestone, 2018). Although earlier hominins had access to a wide array of habitat types (Figure 4), Homo excelled in the successful exploitation of resources from greater ecological contexts. In eastern Africa for example, greater tool use possibly allowed hominins to adapt to microhabitat variability and ecological instability, as evident in the occupation of a broad spectrum of habitats ranging from open grasslands to riparian forests. At Kanjera South, on the Homa Peninsula in Kenya, hominins exhibited comparatively complex land use and toolmaking behaviors as raw materials were transported from over $10 \mathrm{~km}$ (Braun et al., 2008a; Braun et al., 2008b; Braun et al., 2009a; Braun et al., 2009b; Braun and Plummer, 2013). Tools were employed to process a diverse range of resources including animal tissue and underground storage organs and woody and herbaceous plants (Ferraro et al., 2013; Lemorini et al., 2014; Lemorini et al., 2019).

\section{Microhabitat Variability at Oldupai Gorge: A Case Study}

As an "archaeosphere" representing the paleoanthropological record of broader eastern Africa, Oldupai Gorge (formerly Olduvai Gorge) presents an interesting opportunity to explore microhabitat variability across both temporal and spatial scales using multiple paleoecological proxies collected in archaeological and geological horizons (Figure 3, Supplementary Figure S1). Spatial geomorphological, sedimentological, stratigraphic, and geometric analyses are made possible by Oldupai's welldefined Beds: I-IV (2.038 \pm 0.005-0.6 Ma), Masek (600,000-400,000), Ndutu (400,000-32,000), and Naisiusiu $(17,550 \pm 1,000-10,400 \pm 600 \mathrm{BP})$ (Leakey, 1971; Hay, 1976; Deino, 2012; Domínguez-Rodrigo et al., 2013; Diez-Martín et al., 2015). In fact, these beds and marker tuffs, which are exposed for $\sim 25 \mathrm{~km}$ throughout the eastern and western gorges, have made it possible to correlate paleoecological and archaeological datasets across time and space, highlighting the evolution of Homo within a diverse, variable landscape (Cavallo and Blumenschine, 1989; Sikes, 1994; Blumenschine et al., 2012; Uribelarrea et al., 2014; Uribelarrea et al., 2017; Stanistreet et al., 2018).

At the Ewass Oldupa site, where the earliest evidence of the Oldowan is found at Oldupai Gorge (Mercader et al., 2021), hominins used a homogenous toolset within emerging landscapes and volcanically-disturbed habitats multiple times over 235,000 years. The Oldowan assemblage consists of some raw material sourced from up to $\sim 12 \mathrm{~km}$ away and shows technological adaptation to major geomorphic and ecological transitions, whereby stone tool use permitted provisioning across ecologically diverse and complex environments over time and space. Tool use allowed for a more generalist strategy in acquiring plant food resources within a rapidly changing plant landscape that ranged from fern meadows to woodland mosaics, naturally burned landscapes, lakeside woodland/palm 


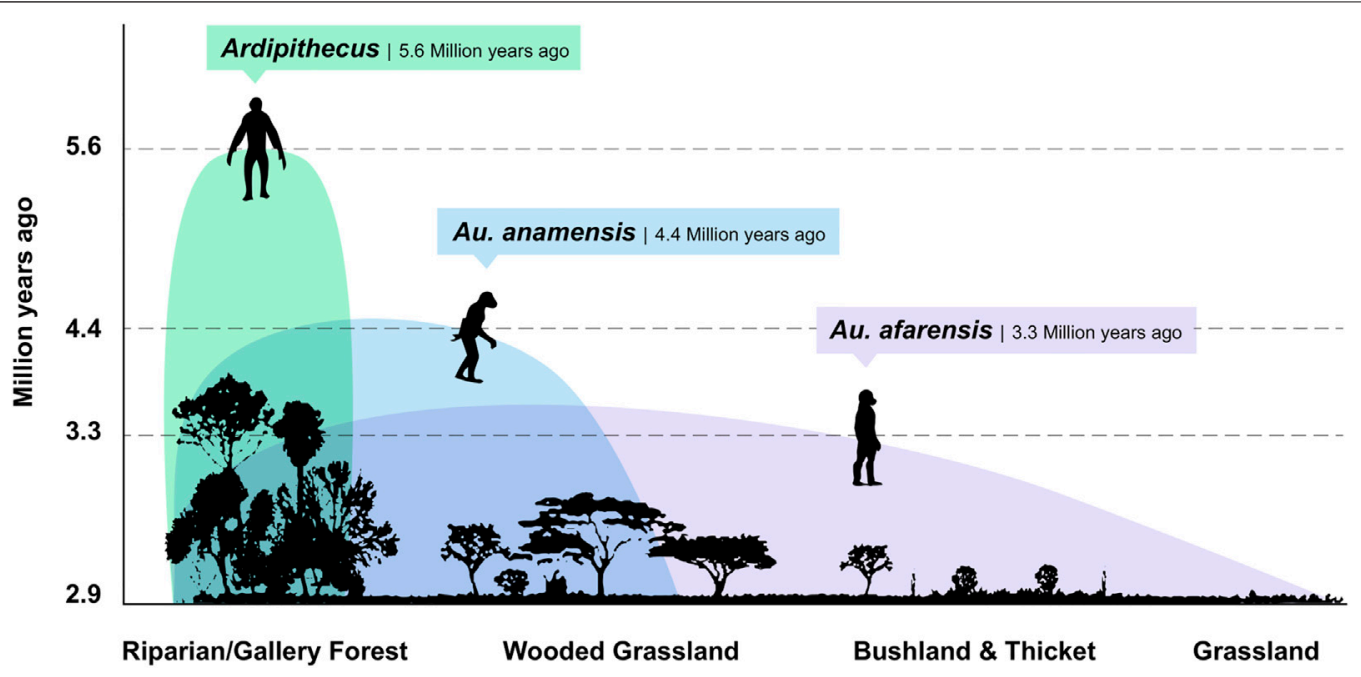

FIGURE 4 | Eastern African hominin paleoecology. The paleoenvironmental record from early hominin bearing sites shows ecologically diversified landscapes. The Mio-Pliocene environments of Ardipithecus have been reconstructed as lakeside, mosaic ecosystems that included permanent wetlands, dense woodlands or gallery forests, wooded grasslands, and grasslands, all of which indicate a degree of spatial variability in the proportion of plant type composition and coverage (WoldeGabriel et al., 1994; WoldeGabriel et al., 2001; Levin et al., 2008; White et al., 2009a; White et al., 2009b; Lovejoy et al., 2009; WoldeGabriel et al., 2009; Cerling et al., 2010). Australopithecus anamensis also frequented $C_{3}$ dominated, closed canopy riparian or gallery forests within an otherwise dry, open acacia woodland catchment (Leakey et al., 1995; Saylor et al., 2019), while Au. afarensis accessed open grasslands, dry bushlands, and riparian woodlands and forests (Johanson et al., 1982; Andrews, 1989). In southern Africa (not shown), Au. africanus likely had access to forests, ecotones, wooded grasslands, and grasslands (Rayner et al., 1993; Sloggett, 2016), and $\mathrm{Au}$. sediba made use of $\mathrm{C}_{3}$-dominated microhabitats within a regional environment of abundant $\mathrm{C}_{4}$ grasses $\sim 2.0 \mathrm{Ma}$ (Bamford et al., 2010; Henry et al., 2012).

groves, and hyper-xeric steppes. This generalist strategy and ability to use emerging landscapes, a finding that is unique for Homo $2.0 \mathrm{Ma}$, depicts complex behavior among early Pleistocene hominins. Early evidence of this environmental response suggests that fundamental aspects of human adaptability was not solely connected to our species' origin (Potts et al., 2020), but rather by the time of our genus' origin and likely played a major role in Homo's ability to expand within and beyond Africa.

Perhaps the most well-known locality at Oldupai is the Frida Leakey Korongo (FLK) site, as it was here at "Level 22" (better known as FLK Zinj) that Mary Leakey discovered P. boisei in 1959 (Leakey, 1959). This level, situated between Tuffs IB and IC (Supplementary Figure S1), was interpreted as an occupation or living floor (Leakey, 1959; Leakey, 1971), where hominins made stone tools to butcher mammals from nearby habitats (Bunn and Kroll, 1986; Blumenschine, 1995). Situated in uppermost Bed I and only $\sim 100 \mathrm{~m}$ north of FLK Zinj is FLK North, one of the richest Pleistocene archaeological deposits known (Leakey, 1971; Domínguez-Rodrigo et al., 2010). FLK N is a $3.0 \mathrm{~m}, 15,000$-years sequence in Upper Bed I subdivided into nine archaeological units dated between 1.803 Ma and 1.818 Ma (Deino, 2012). The marker tuffs that cap each site, and the organic rich silty-waxy clays directly in contact below the tuffs, are observable in exposures for more than $2 \mathrm{~km}$ throughout the main confluence of the gorge (Figure 3). These organic-rich clays were deposited on the alluvial fans and floodplains surrounding paleo-Lake Oldupai and have been the focus of recent paleoecological, microhabitat variability studies.
There is evidence from plant wax biomarkers (Magill et al., 2015; Patalano, 2019) and phytoliths (Barboni et al., 2010; Blumenschine et al., 2012; Arráiz et al., 2017; Itambu, 2019), collected from organic rich clays directly in contact with both Tuff IC and Tuff IF, for ecologically diverse hominin microhabitats throughout the Oldupai depositional basin (Figure 3, Figure 5). A combination of plant wax biomarkers and their stable carbon isotopes, phenol derivatives of lignin which distinguishes woody from herbaceous plants, fern and sedge biomarkers that demarcate wetlands, and phytoliths revealed the geographic distribution of different microhabitats across the FLK Zinj paleo-landscape (Magill et al., 2015; Arráiz et al., 2017). Abrupt changes from wetland vegetation, to dense $C_{3}$ woody coverage, to open $\mathrm{C}_{4}$ grassland were identified at meterlevel scales, showing that FLK Zinj was a forest microhabitat adjacent to a wetland situated within a greater grassland catchment (Magill et al., 2015). Compounded with the phytolith results, which are dominated by woody morphotypes and supported by grass, sedge, and palm types (Arráiz et al., 2017), both datasets indicate relatively wet and wooded microhabitats across the FLK Zinj landscape, situated within a catchment dominated by arid-adapted $\mathrm{C}_{4}$ species. Additionally, plant wax carbon and hydrogen isotopes and biogenic silica also show that $\mathrm{C}_{3}$ plants dominated the archaeological assemblage at FLK N (Itambu, 2019; Patalano, 2019). Phytolith and plant wax data from the clays directly below Tuff IF indicate that at the top of Bed I, Oldupai's landscape was variable mosaic with areas of dense vegetation and abundant fresh water (e.g., FLK N), Typha dominated wetlands, open grassland, and ecotones (Figure 5). 

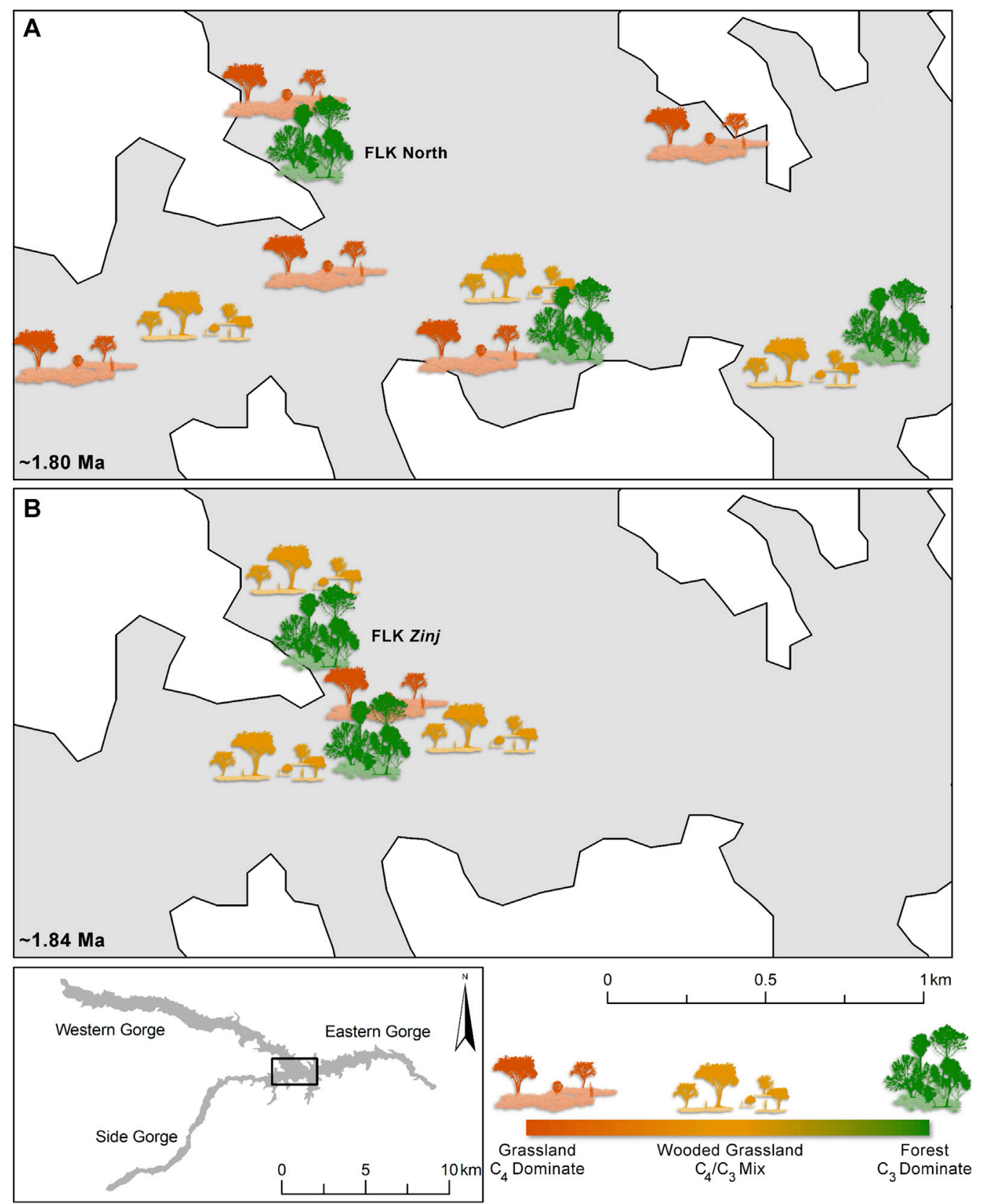

FIGURE 5 | Microhabitat Variability at Oldupai Gorge at $\sim 1.8$ and $\sim 1.84$ Ma reconstructed from plant wax biomarker and phytolith analyses. (A) Data from the clays directly below 1.8 Ma Tuff IF (Itambu, 2019; Patalano, 2019). (B) Data from the 1.84 FLK Zinj horizon (Magill et al., 2015; Arráiz et al., 2017). Microhabitat icons are not to scale but rather represent the reconstructed plant landscape structure at given sampling locations based on plant proxies.

Interpreted as a woodland or even a true forest, the reconstructed $\mathrm{C}_{3}$ environment at FLK $\mathrm{N}$ suggests that it may have been similar to the dense evergreen forest that now flourishes near freshwater springs percolating out of the rift escarpment on the northwestern and western shores of Lake Manyara.

The archaeology and paleontology of each site indicate that hominins butchered animals at FLK Zinj (Leakey, 1971; Blumenschine, 1995; Dominguez Rodrigo, 1997; DomínguezRodrigo and Barba, 2007; Domínguez-Rodrigo et al., 2014), but processed hard-shelled nuts and fruits at FLK $\mathrm{N}$ (Domínguez-Rodrigo et al., 2007a; Diez-Martín et al., 2010; Domínguez-Rodrigo et al., 2010). Apart from the FLK Zinj Level 22 and David's Site (DS) (Domínguez-Rodrigo et al., 2017a), no other Bed I site provides evidence for access and the direct consumption of animals by hominins (DomínguezRodrigo et al., 2007b; Domínguez-Rodrigo et al., 2017b). That is, all other sites seemingly involved the use of Oldowan tools for plant processing (cf. Blumenschine, 1995). Woody vegetation 
patches may have been the incentive that enticed hominins to use FLK Zinj and FLK $\mathrm{N}$ as focal points on the landscape to process both plant and animal foodstuffs acquired within the microhabitats that developed across Oldupai's basin.

\section{EXPANDING THE MICROHABITAT VARIABILITY FRAMEWORK}

Over the past two decades, spatial paleoecological analyses have allowed us to better understand the ways in which hominins adapted to microhabitat variability across space and time. Others have brought attention to the role microhabitat variability played in creating potentially resource-rich habitat types and opportunities for niche diversification and specialization amongst hominins (Stern, 1993; Foley, 1995; Cachel and Harris, 1998; King and Bailey, 2006; Reynolds et al., 2015). Higher spatial resolution environmental proxy data and moreprecise dating techniques (Herries et al., 2020; Martin et al., 2021), even demonstrate the influence of microhabitat variability in shaping hominin evolutionary biology and anatomy. Although the focus has been on early Homo from around $2.0 \mathrm{Ma}$ and at Oldupai Gorge, morphological differences between $P$. robustus from Drimolen and Swartkrans in South Africa, which are only $\sim 6 \mathrm{~km}$ apart, represent highly resolved evidence for microevolutionary change associated with ecological variability across a short time frame and restricted geography (Martin et al., 2021). Differences in mandibular morphology between specimens from each location developed as a dietary adaptation to a marginal ecological setting. That is, the slightly younger but more robust Swartkrans $P$. robustus exhibit a more efficient bite force, likely representing a microevolutionary change within this population due to a dietary shift toward foods that were mechanically challenging to process (Sponheimer et al., 2006). This coincided with a reduction in ecological productivity following increased aridity and smallscale microhabitat reorganizations (Caley et al., 2018).

The Oldupai case study highlights how global and regional climate, tectonic and sudden geomorphological activity, and hydrogeography all contribute to spatially variable, often ecologically diverse and environmentally complex biomes, ecoregions, habitats, and microhabitats. Based on the available evidence, the ability of the genus Homo to adapt and thrive across regions of both high and low ecological diversity, as well as within ecosystems that change drastically, was in place by at least $2.0 \mathrm{Ma}$ and likely assisted in technological developments and dispersals within and beyond Africa later in time. For instance, $H$. sapiens' successful ability to innovate under decreased resource predictability was cultivated by an evolutionary history of navigating complex and diverse ecological transitions. In the Olorgesailie basin of Kenya, the onset of the eastern African Middle Stone Age (MSA) is tied to H. sapiens behavioral and technological adaptation to habitat and resource variability (Potts et al., 2020). Between 400 and $320 \mathrm{Ka}$, dynamic landscape change through space and time (triggered by geologic, climatic, and ecological factors) likely led to lower resource reliability and may have necessitated that $H$. sapiens adopt MSA types of stone tool technology as a hunting innovation (Potts et al., 2020), specifically as distinct ecological zones developed over a distance of less than $20 \mathrm{~km}$ following increases in Middle-to LatePleistocene aridification and environmental variability (Owen et al., 2018).

By filling a "generalist specialist" niche, Homo and especially $H$. sapiens, excelled at adapting to environmental extremes and exploiting microhabitat variability across deserts, at high altitudes and latitudes, and within tropical rainforests, was able to successfully innovate under periods of decreased resource predictability (e.g., Potts et al., 2020), and construct their own environments (e.g., Thompson et al., 2021). As this ability to adapt and thrive in dynamic environments was already wellestablished in Homo, the addition of unique behavior like complex ecological knowledge and plant landscape modification and construction, eventually allowed $H$. sapiens to occupy of a wide diversity of ecological settings across the majority of the Earth's continents (review in Roberts and Stewart, 2018).

The microhabitat variability framework suggests that as African landscapes were impacted spatially by tectonic activity and hydrogeology, and temporally by orbital forcing and rainfall seasonality, the flexibility of Homo was likely beneficial in unstable, unpredictable, or unfamiliar environments. As tool innovation and use, specifically after $2.0 \mathrm{Ma}$, allowed for a more generalist strategy in acquiring plant and animal food resources across diverse and rapidly changing landscapes, the adaptive versatility of Homo and the capacity to adjust to new habitat types may have helped to withstand periods of extreme climate variability throughout the Pleistocene. There are numerous hypotheses regarding climatic variability driving hominin evolution and the eventual appearance and dispersal of our species (Table 3). However, there has been less consideration of ecological variability across space, largely due to sampling and methodological issues (also Faith et al., 2021). With new, transdisciplinary approaches toward reconstructing hominin environments directly on-site and across archaeological and geological horizons, we can address and test the following research questions:

- Did Pliocene and Pleistocene hominins rely on oases of woodland/forest habitats within wider grassland ecoregions? If so, to what extent and for what purpose (e.g., protection, food)?

- Did dispersals of hominins simply occur when larger ecoregions expanded (e.g., "savannah" corridors (Dennell and Roebroeks, 2005))?

- On the other hand, did geographic ecological variability always play a role in hominin dispersals first across Africa and then beyond?

- How can we better factor the microhabitat variability framework into paleoclimatic, paleoenvironmental, and evolutionary models? That is, can we go beyond the natural selection and speciation models that use distal proxy records to compare climate windows to biome and ecoregion changes and the ensuing influence on genetic variability and human evolution? 
To tackle these questions, future research designs should consider correlating and sampling terrestrial sediments from archaeological and geological horizons to collect and analyze such environmental proxies as outlined in Table 2. This would involve identifying geologic strata and their geographic extent, collecting sediments from correlated deposits, testing organic preservation, and then paleoenvironmental reconstruction through proxy analyses. By understanding the spatial variability of environments and locations of concentrated archaeological assemblages, we can then better interpret hominin land-use patterns and activity within a regional and global climatic context to discern the ways in which Homo adapted to microhabitat variability over time and space.

\section{CONCLUSION}

Microhabitat variability provides a framework within which to understand the adaptability of hominins across spatially and temporally changing, sometimes rapidly, plant landscapes. Because members of the genus Homo were already adept at exploiting diverse food-types from multiple habitats including disturbed and emerging environments by $2.0 \mathrm{Ma}$, they successfully navigated ecosystem reorganization during pulses of climate instability throughout the Pleistocene. By incorporating paleoecological analyses for studying microhabitat variability in future paleoanthropological research, we can better interpret the evolutionary importance of climatic and non-climatic stressors and plant landscape responses to then validate or refute the habitat specific or variability hypotheses.

A microhabitat variability approach incorporates evidence for adaptations involving tool use, demonstrated by Oldowan hominins from Oldupai, high-resolution environmental proxy evidence for meter-scale changes in hominin landscape ecology, and field and laboratory methodologies for identifying patches of distinct plant communities that may have offered unique food resources and shelter. With research designs that focus on exploring and understanding hominin microhabitat variability, we can uncover further information relating to major adaptive morphological, technological, and cultural features that have not been fully addressed by human evolution environmental hypotheses. This approach, therefore, has the potential to significantly contribute to current interpretations of hominin evolutionary processes within an ecological framework by uncovering additional evidence for Homo's successful exploitation of resources under wide-ranging climate zones and ecoregions within and then beyond Africa.

\section{REFERENCES}

Aiello, L. C., and Key, C. (2002). Energetic Consequences of Being aHomo Erectus Female. Am. J. Hum. Biol. 14, 551-565. doi:10.1002/ajhb.10069

Aiello, L. C., and Wells, J. C. K. (2002). Energetics and the Evolution of the Genus Homo. Annu. Rev. Anthropol. 31, 323-338. doi:10.1146/annurev.anthro.31.040402.085403

\section{AUTHOR CONTRIBUTIONS}

$\mathrm{RP}, \mathrm{EF}, \mathrm{RH}$, and PR conceived the concepts presented throughout; all authors wrote and revised the manuscript.

\section{FUNDING}

For financial support, we acknowledge the Canadian Social Sciences and Humanities Research Council under its Partnership Grant Program (no. 895-2016-1017 to Julio Mercader of the University of Calgary), the Explorers Club Exploration Fund Grant (to RP), the Ruggles-Gates Fund for Biological Anthropology (to RP), and the Max Planck Society.

\section{ACKNOWLEDGMENTS}

We thank to Dr. Julio Mercader of the University of Calgary for doctoral research financial support of R. P. and M. I. All authors would like to thank the Max Planck society for funding. We are also very grateful to Michelle O'Reilly for her assistance in preparing figures. Additionally, we are especially thankful to Dr. Jessica Thompson and Dr. Chenglong Deng for their helpful and constructive comments and for taking the time and effort to help us improve and strengthen our manuscript, and Drs. Huw Groucutt, Amy Prendergast, and Felix Riede for organizing and editing the Extreme Events in Human Evolution: From the Pliocene to the Anthropocene special issue. For research conducted in Tanzania, we thank the Tanzanian Ministry of Natural Resources and Tourism through its Antiquities Division [14/2017/2018], the Ngorongoro Conservation Area [BE.504/ 620/01/53], the Tanzanian export license from the Antiquities Division [EA.150/297/01: 5/2018/2019], and the Tanzanian Executive Secretary from the Mining Commission [00001258] who authorized sample exportation.

\section{SUPPLEMENTARY MATERIAL}

The Supplementary Material for this article can be found online at: https://www.frontiersin.org/articles/10.3389/feart.2021.787669/ full\#supplementary-material

Supplementary Figure S1 | Stratigraphic subsections of Bed I. The expanded profile is of the FLK-N Oldowan site. Ewass Oldupa is located stratigraphically below Tuff IA and dates to $2.038 \pm 0.005 \mathrm{Ma}$ (Mercader et al., 2021). Stratigraphic and archeological units are not to scale except for the $3 \mathrm{~m}$ FLK-N profile. Dates and stratigraphy adapted from Ashley et al., 2010; Deino, 2012; Diez-Martín et al., 2015; Domínguez-Rodrigo et al., 2007; Hay, 1976; McHenry and Stanistreet, 2018; Stanistreet, 2012.

Albert, R. M., Bamford, M. K., and Cabanes, D. (2009). Palaeoecological Significance of Palms at Olduvai Gorge, Tanzania, Based on Phytolith Remains. Quat. Int. 193, 41-48. doi:10.1016/j.quaint.2007.06.008

Albert, R. M., Bamford, M. K., and Cabanes, D. (2006). Taphonomy of Phytoliths and Macroplants in Different Soils from Olduvai Gorge (Tanzania) and the Application to Plio-Pleistocene Palaeoanthropological Samples. Quat. Int. 148, 78-94. doi:10.1016/j.quaint.2005.11.026 
Albert, R. M., Bamford, M. K., Stanistreet, I. G., Stollhofen, H., Rivera-Rondón, C. A., Njau, J. K., et al. (2018). River-fed Wetland Palaeovegetation and Palaeoecology at the HWK W Site, Bed I, Olduvai Gorge. Rev. Palaeobotany Palynology 259, 223-241. doi:10.1016/j.revpalbo.2018.09.010

Albert, R. M., and Bamford, M. K. (2012). Vegetation during UMBI and Deposition of Tuff IF at Olduvai Gorge, Tanzania (Ca. 1.8 Ma) Based on Phytoliths and Plant Remains. J. Hum. Evol. 63, 342-350. doi:10.1016/j.jhevol.2011.05.010

Alemseged, Z., Wynn, J. G., Geraads, D., Reed, D., Andrew Barr, W., Bobe, R., et al. (2020). Fossils from Mille-Logya, Afar, Ethiopia, Elucidate the Link between Pliocene Environmental Changes and Homo Origins. Nat. Commun. 11 (1), 2480. doi:10.1038/s41467-020-16060-8

Andrews, P. J. (1989). Palaeoecology of Laetoli. J. Hum. Evol. 18, 173-181. doi:10.1016/0047-2484(89)90071-7

Antón, S. C. (2003). Natural History of Homo Erectus. Am. J. Phys. Anthropol. 122 (37), 126-176. doi:10.1002/ajpa.10399

Antón, S. C., Potts, R., and Aiello, L. C. (2014). Evolution of Early Homo : An Integrated Biological Perspective. Science 345 (6192), 1236828. doi:10.1126/ science. 1236828

Archibald, S., Staver, A. C., and Levin, S. A. (2012). Evolution of Human-Driven Fire Regimes in Africa. Proc. Natl. Acad. Sci. 109 (3), 847-852. doi:10.1073/ pnas.1118648109

Arráiz, H., Barboni, D., Ashley, G. M., Mabulla, A., Baquedano, E., and Domínguez-Rodrigo, M. (2017). The FLK Zinj Paleolandscape: Reconstruction of a 1.84 Ma Wooded Habitat in the FLK Zinj-AMK-PTKDS Archaeological Complex, Middle Bed I (Olduvai Gorge, Tanzania). Palaeogeogr. Palaeoclimatol. Palaeoecol. 488, 9-20. doi:10.1016/ j.palaeo.2017.04.025

Bamford, M. K., Albert, R. M., and Cabanes, D. (2006). Plio-Pleistocene Macroplant Fossil Remains and Phytoliths from Lowermost Bed II in the Eastern Palaeolake Margin of Olduvai Gorge, Tanzania. Quat. Int. 148, 95-112. doi:10.1016/j.quaint.2005.11.027

Bamford, M. K., Stanistreet, I. G., Stollhofen, H., and Albert, R. M. (2008). Late Pliocene Grassland from Olduvai Gorge, Tanzania. Palaeogeogr. Palaeoclimatol. Palaeoecol. 257, 280-293. doi:10.1016/j.palaeo.2007.09.003

Bamford, M., Neumann, F., Pereira, L., Scott, L., Dirks, P., and Berger, L. (2010). Botanical Remains from a Coprolite from the Pleistocene Hominin Site of Malapa, Sterkfontein Valley, South Africa. Palaeontol. africana 45, 23-28.

Barboni, D., Ashley, G. M., Dominguez-Rodrigo, M., Bunn, H. T., Mabulla, A. Z. P., and Baquedano, E. (2010). Phytoliths Infer Locally Dense and Heterogeneous Paleovegetation at FLK North and Surrounding Localities during Upper Bed I Time, Olduvai Gorge, Tanzania. Quat. Res. 74, 344-354. doi:10.1016/ j.yqres.2010.09.005

Barboni, D., Bonnefille, R., Alexandre, A., and Meunier, J. D. (1999). Phytoliths as Paleoenvironmental Indicators, West Side Middle Awash Valley, Ethiopia. Palaeogeogr. Palaeoclimatol. Palaeoecol. 152, 87-100. doi:10.1016/s00310182(99)00045-0

Barboni, D. (2014). Vegetation of Northern Tanzania during the Plio-Pleistocene: A Synthesis of the Paleobotanical Evidences from Laetoli, Olduvai, and Peninj Hominin Sites. Quat. Int. 322-323, 264-276. doi:10.1016/. quaint.2014.01.016

Bennett, A. C., Dargie, G. C., Cuni-Sanchez, A., Tshibamba Mukendi, J., Hubau, W., Mukinzi, J. M., et al. (2021). Resistance of African Tropical Forests to an Extreme Climate Anomaly. Proc. Natl. Acad. Sci. USA 118 (21), e2003169118. doi:10.1073/pnas.2003169118

Berger, L. R., de Ruiter, D. J., Churchill, S. E., Schmid, P., Carlson, K. J., Dirks, P. H., et al. (2008). Australopithecus Sediba: A New Species of Homo-like Australopith from South Africa. Science 328, 195-204. doi:10.1126/science.1184944

Bibi, F., and Kiessling, W. (2015). Continuous Evolutionary Change in PlioPleistocene Mammals of Eastern Africa. Proc. Natl. Acad. Sci. USA 112, 10623-10628. doi:10.1073/pnas.1504538112

Bibi, F., Pante, M., Souron, A., Stewart, K., Varela, S., Werdelin, L., et al. (2018). Paleoecology of the Serengeti during the Oldowan-Acheulean Transition at Olduvai Gorge, Tanzania: The Mammal and Fish Evidence. J. Hum. Evol. 120, 48-75. doi:10.1016/j.jhevol.2017.10.009

Bliege Bird, R., McGuire, C., Bird, D. W., Price, M. H., Zeanah, D., and Nimmo, D. G. (2020). Fire Mosaics and Habitat Choice in Nomadic Foragers. Proc. Natl. Acad. Sci. USA 117 (23), 12904-12914. doi:10.1073/pnas.1921709117

Blumenschine, R. J. (1995). Percussion marks, Tooth marks, and Experimental Determinations of the Timing of Hominid and Carnivore Access to Long Bones at FLK Zinjanthropus, Olduvai Gorge, Tanzania. J. Hum. Evol. 29, 21-51. doi:10.1006/jhev.1995.1046

Blumenschine, R. J., Stanistreet, I. G., Njau, J. K., Bamford, M. K., Masao, F. T., Albert, R. M., et al. (2012). Environments and Hominin Activities across the FLK Peninsula during Zinjanthropus Times (1.84 Ma), Olduvai Gorge, Tanzania. J. Hum. Evol. 63, 364-383. doi:10.1016/j.jhevol.2011.10.001

Blumenthal, S. A., Levin, N. E., Brown, F. H., Brugal, J.-P., Chritz, K. L., Harris, J. M., et al. (2017). Aridity and Hominin Environments. Proc. Natl. Acad. Sci. USA 114 (28), 7331-7336. doi:10.1073/pnas.1700597114

Bobe, R., and Eck, G. (2001). Responses of African Bovids to Pliocene Climatic Change. Paleobiology 27 (Suppl. to number 2), 1-47. doi:10.1666/00948373(2001)027<0001:roabtp $>2.0 . c 0 ; 2$

Bonnefille, B. (1995). "A Reassessment of the Plio-Pleistocene Pollen Record of East Africa," in Paleoclimate and Evolution, with Emphasis on Human Origins. Editors E. Vrba, G. Denton, T. Partridge, and L. Burckle (New Haven: Yale University Press), 299-310.

Boutin, S., and Lane, J. E. (2014). Climate Change and Mammals: Evolutionary versus Plastic Responses. Evol. Appl. 7 (1), 29-41. doi:10.1111/eva.12121

Braun, D. R., and Plummer, T. W. (2013). "Oldowan Technology at Kanjera South: Technological Diversity on the Homa Peninsula," in Africa: Cradle of Humanity: Recent Discoveries. Editor M. Sahnouni (Algeria: CNRPAH), 131-145.

Braun, D. R., Aldeias, V., Archer, W., Arrowsmith, J. R., Baraki, N., Campisano, C. J., et al. (2019). Earliest Known Oldowan Artifacts at $>2.58$ Ma from LediGeraru, Ethiopia, Highlight Early Technological Diversity. Proc. Natl. Acad. Sci. USA 116 (24), 201820177. doi:10.1073/pnas.1820177116

Braun, D. R., Harris, J. W. K., and Maina, D. N. (2009a). Oldowan Raw Material Procurement and Use: Evidence from the Koobi Fora Formation. Archaeometry 51 (1), 26-42. doi:10.1111/j.1475-4754.2008.00393.x

Braun, D. R., Plummer, T., Ditchfield, P., Ferraro, J. V., Maina, D., Bishop, L. C., et al. (2008a). Oldowan Behavior and Raw Material Transport: Perspectives from the Kanjera Formation. J. Archaeological Sci. 35, 2329-2345. doi:10.1016/ j.jas.2008.03.004

Braun, D. R., Plummer, T., Ferraro, J. V., Ditchfield, P., and Bishop, L. C. (2009b). Raw Material Quality and Oldowan Hominin Toolstone Preferences: Evidence from Kanjera South, Kenya. J. Archaeological Sci. 36, 1605-1614. doi:10.1016/ j.jas.2009.03.025

Braun, D. R., Pobiner, B. L., and Thompson, J. C. (2008b). An Experimental Investigation of Cut Mark Production and Stone Tool Attrition. J. Archaeological Sci. 35, 1216-1223. doi:10.1016/j.jas.2007.08.015

Brittingham, A., Hren, M. T., Hartman, G., Wilkinson, K. N., Mallol, C., Gasparyan, B., et al. (2019). Geochemical Evidence for the Control of Fire by Middle Palaeolithic Hominins. Sci. Rep. 9 (15368). doi:10.1038/s41598-01951433-0

Brockhurst, M. A., Chapman, T., King, K. C., Mank, J. E., Paterson, S., and Hurst, G. D. D. (2014). Running with the Red Queen: the Role of Biotic Conflicts in Evolution. Proc. R. Soc. B. 281, 20141382. doi:10.1098/rspb.2014.1382

Bunn, H. T., Kroll, E. M., Ambrose, S. H., Behrensmeyer, A. K., Binford, L. R., Blumenschine, R. J., et al. (1986). Systematic Butchery by Plio/Pleistocene Hominids at Olduvai Gorge, Tanzania [and Comments and Reply]. Curr. Anthropol. 27, 431-452. doi:10.1086/203467

Cabanes, D. (2020). in Phytolith Analysis in Paleoecology and ArchaeologyHandbook for the Analysis of Micro-particles in Archaeological Samples. Editor A.G. Henry (Cham, Switzerland: Springer Nature Switzerland), 304.

Cachel, S., and Harris, J. W. K. (1998). "The Lifeways of Homo Erectus Inferred from Archaeology and Evolutionary Ecology: a Perspective from East Africa," in Early Human Behaviour in Global Context. Editors M.D. Petraglia and R. Korisettar (London: Routledge), 108-132.

Caley, T., Extier, T., Collins, J. A., Schefuß, E., Dupont, L., Malaizé, B., et al. (2018). A Two-Million-Year-Long Hydroclimatic Context for Hominin Evolution in southeastern Africa. Nature 560 (7716), 76-79. doi:10.1038/ s41586-018-0309-6

Campisano, C. J., and Feibel, C. S. (2008). "Depositional Environments and Stratigraphic Summary of the Pliocene Hadar Formation at Hadar, Afar Depression, Ethiopia," in The Geology of Early Humans in the Horn of Africa. Editors J. Quade and J. G. Wynn (McLean: Geological Society of America). doi:10.1130/2008.2446(08) 
Castañeda, I. S., Mulitza, S., Schefuß, E., Lopes dos Santosa, R. A., Sinninghe Damste, J. S., and Schouten, S. (2009). Wet Phases in the Sahara/Sahel Region and Human Migration Patterns in North Africa. Proc. Natl. Acad. Sci. 106 (48), 20159-20163.

Cavallo, J. A., and Blumenschine, R. J. (1989). Tree-stored Leopard Kills: Expanding the Hominid Scavenging Niche. J. Hum. Evol. 18, 393-399. doi:10.1016/0047-2484(89)90038-9

Cerling, T. E., Harris, J. M., Ambrose, S. H., Leakey, M. G., and Solounias, N. (1997). Dietary and Environmental Reconstruction with Stable Isotope Analyses of Herbivore Tooth Enamel from the Miocene Locality of Fort Ternan, Kenya. J. Hum. Evol. 33, 635-650. doi:10.1006/jhev.1997.0151

Cerling, T. E., Levin, N. E., Quade, J., Wynn, J. G., Fox, D. L., Kingston, J. D., et al. (2010). Comment on the Paleoenvironment of Ardipithecus Ramidus. Science 328 (5982), 1105. doi:10.1126/science.1185274

Cerling, T. E., Wynn, J. G., Andanje, S. A., Bird, M. I., Korir, D. K., Levin, N. E., et al. (2011). Woody Cover and Hominin Environments in the Past 6 Million Years. Nature 476, 51-56. doi:10.1038/nature10306

Christensen, J. H., and Kanikicharla, K. K. (2013). "Climate Phenomena and Their Relevance for Future Regional Climate Change," in Climate Change 2013: The Physical Science Basis. Contribution of Working Group I to the Fifth Assessment Report of the Intergovernmental Panel on Climate Change. Editors T.F. Stocker, D. Qin, G. K. Plattner, M. Tignor, S. K. Allen, J. Boschung, et al. (Cambridge, UK: Cambridge University Press).

Colcord, D. E., Shilling, A. M., Sauer, P. E., Freeman, K. H., Njau, J. K., Stanistreet, I. G., et al. (2018). Sub-Milankovitch Paleoclimatic and Paleoenvironmental Variability in East Africa Recorded by Pleistocene Lacustrine Sediments from Olduvai Gorge, Tanzania. Palaeogeogr. Palaeoclimatol. Palaeoecol. 495, 284-291. doi:10.1016/j.palaeo.2018.01.023

Cole, L. E. S., Bhagwat, S. A., and Willis, K. J. (2014). Recovery and Resilience of Tropical Forests after Disturbance. Nat. Commun. 5 (1), 3906. doi:10.1038/ ncomms 4906

Collins, J. A., Carr, A. S., Schefuß, E., Boom, A., and Sealy, J. (2017). Investigation of Organic Matter and Biomarkers from Diepkloof Rock Shelter, South Africa: Insights into Middle Stone Age Site Usage and Palaeoclimate. J. Archaeological Sci. 85 (51-65). doi:10.1016/j.jas.2017.06.011

Committee on the Earth System Context for Hominin Evolution (2010). Understanding Climate's Influence on Human Evolution. Washington, DC: National Research Council.

Copeland, S. (2007). Vegetation and Plant Food Reconstruction of Lowermost Bed II, Olduvai Gorge, Using Modern Analogs. J. Hum. Evol. 53, 146-175. doi:10.1016/j.jhevol.2007.03.002

Coppens, A. C. (1968). Sur la decouverte dans le Pleistocene inferieur de la valle de l'Omo (Ethiopie) d'une mandibule d'Australopithecien [On the discovery in the Lower Pleistocene Omo Valley (Ethiopia) of an Australopithecine Mandible]. Comptes Rendus des Séances de l'Académie des Sci. (in French) 265, 589-590.

Coppens, Y. (1994). East Side Story: The Origin of Humankind. Sci. Am. 270 (5), 88-95. doi:10.1038/scientificamerican0594-88

Dart, R. A. (1925). Australopithecus Africanus the Man-Ape of South Africa. Nature 115 (2884), 195-199. doi:10.1038/115195a0

de Oliveira, C. P., Aímola, L., Ambrizzi, T., and Freitas, A. C. V. (2018). The Influence of the Regional Hadley and Walker Circulations on Precipitation Patterns over Africa in El Niño, La Niña, and Neutral Years. Pure Appl. Geophys. 175 (6), 2293-2306. doi:10.1007/s00024-018-1782-4

Deino, A. L. (2012). 40Ar/39Ar Dating of Bed I, Olduvai Gorge, Tanzania, and the Chronology of Early Pleistocene Climate Change. J. Hum. Evol. 63 (2), 251-273. doi:10.1016/j.jhevol.2012.05.004

deMenocal, P. B. (2004). African Climate Change and Faunal Evolution during the Pliocene-Pleistocene. Earth Planet. Sci. Lett. 220, 3-24. doi:10.1016/s0012$821 x(04) 00003-2$

deMenocal, P. B. (2011). Climate and Human Evolution. Science 331, 540-542. doi:10.1126/science. 1190683

Dennell, R., and Roebroeks, W. (2005). An Asian Perspective on Early Human Dispersal from Africa. Nature 438, 1099-1104. doi:10.1038/nature04259

Diefendorf, A. F., and Freimuth, E. J. (2017). Extracting the Most from Terrestrial Plant-Derived $N$-Alkyl Lipids and Their Carbon Isotopes from the Sedimentary Record: A Review. Org. Geochem. 103, 1-21. doi:10.1016/ j.orggeochem.2016.10.016
Diez-Martín, F., Sánchez Yustos, P., Uribelarrea, D., Baquedano, E., Mark, D. F., Mabulla, A., et al. (2015). The Origin of the Acheulean: The 1.7 Million-YearOld Site of FLK West, Olduvai Gorge (Tanzania). Nat. Scientific Rep. 5 (17839), 1-9.

Diez-Martín, F., Yustos, P. S., Domínguez-Rodrigo, M., Mabulla, A., Bunn, H., Ashley, G. M., et al. (2010). New Insights into Hominin Lithic Activities at FLK North Bed I, Olduvai Gorge, Tanzania. Quat. Res. 74, 376-387.

Dominguez Rodrigo, M. (1997). Meat Eating by Early Hominids at the FLK 22 Zinjanthropus Site, Olduvai Gorge, Tanzania: an Experimental Approach Using Cut Mark Data. J. Hum. Evol. 33, 669-690.

Domínguez-Rodrigo, M., Barba, R., de la Torre, I., and Mora, R. (2007a). "A Cautionary Tale about Early Archaeological Sites: a Reanalysis of FLK North 6," in Deconstructing Olduvai: A Taphonomic Study of the Bed I Sites. Editors M. Domínguez-Rodrigo, R. Barba, and A. G. Egeland (Dordrecht, Netherlands: Springer), 101-126.

Domínguez-Rodrigo, M., and Barba, R. (2007). “The Behavioral Meaning of Cut marks at the FLK Zinj Level: the Carnivore-Hominid-Carnivore Hypothesis Falsified (II)," in Deconstructing Olduvai: A Taphonomic Study of the Bed I Sites. Editors M. Dominguez-Rodrigo, R. Barba, and C. P. Egeland (Dordrecht, Netherlands: Springer), 75-100.

Domínguez-Rodrigo, M., Bunn, H. T., and Yravedra, J. (2014). A Critical Reevaluation of Bone Surface Modification Models for Inferring Fossil Hominin and Carnivore Interactions through a Multivariate Approach: Application to the FLK Zinj Archaeofaunal Assemblage (Olduvai Gorge, Tanzania). Quat. Int. 322-323, 32-43. doi:10.1016/j.quaint.2013.09.042

Domínguez-Rodrigo, M., Cobo-Sánchez, L., Uribelarrea, D., Arriaza, M. C., Yravedra, J., Gidna, A., et al. (2017b). Spatial Simulation and Modelling of the Early Pleistocene Site of DS (Bed I, Olduvai Gorge, Tanzania): a Powerful Tool for Predicting Potential Archaeological Information from Unexcavated Areas. Boreas 46 (4), 805-815.

Domínguez-Rodrigo, M., Cobo-Sánchez, L., Uribelarrea, D., Arriaza, M. C., Yravedra, J., Gidna, A., et al. (2017a). Spatial Simulation and Modelling of the Early Pleistocene Site of DS (Bed I, Olduvai Gorge, Tanzania): a Powerful Tool for Predicting Potential Archaeological Information from Unexcavated Areas. Boreas 46 (4), 805-815. doi:10.1111/bor.12252

Domínguez-Rodrigo, M., Egido, R. B., and Egeland, C. P. (2007b). Deconstructing Olduvai: A Taphonomic Study of the Bed I Sites. Dordrecht, Netherlands: Springer.

Domínguez-Rodrigo, M., Mabulla, A., Bunn, H., Diez Martin, F., Baquedano, E., Barboni, D., et al. (2010). Disentangling Hominin and Carnivore Activities Near a spring at FLK North (Olduvai Gorge, Tanzania). Quat. Res. 74, 363-375.

Domínguez-Rodrigo, M., Pickering, T. R., Baquedano, E., Mabulla, A., Mark, D. F., Musiba, C., et al. (2013). First Partial Skeleton of a 1.34-Million-Year-Old Paranthropus Boisei from Bed II, Olduvai Gorge, Tanzania. PLOS One 8 (12), e80347. doi:10.1371/journal.pone.0080347

Duke, H., Feibel, C., and Harmand, S. (2021). Before the Acheulean: The Emergence of Bifacial Shaping at Kokiselei 6 (1.8 Ma), West Turkana, Kenya. J. Hum. Evol. 159, 103061. doi:10.1016/j.jhevol.2021.103061

Evolution, C. o. t. E. S. C. f. H. (2010). Understanding Climate's Influence on Human Evolution. Washington, DC: National Research Council.

Faegri, K., and Iversen, J. (1989). Textbook of Pollen Analysis. Chichester: John Wiley \& Sons.

Faith, J. T., Du, A., Behrensmeyer, A. K., Davies, B., Patterson, D. B., Rowan, J., et al. (2021). Rethinking the Ecological Drivers of Hominin Evolution. Trends Ecol. Evol. 36 (9), 797-807. doi:10.1016/j.tree.2021.04.011

Faith, J. T., Rowan, J., and Du, A. (2019). Early Hominins Evolved within Nonanalog Ecosystems. Proc. Natl. Acad. Sci. USA 116 (43), 21478-21483. doi:10.1073/pnas.1909284116

Feakins, S. J., deMenocal, P. B., and Eglinton, T. I. (2005). Biomarker Records of Late Neogene Changes in Northeast African Vegetation. Geol 33, 977-980. doi:10.1130/g21814.1

Feakins, S. J., Eglinton, T. I., and deMenocal, P. B. (2007). A Comparison of Biomarker Records of Northeast African Vegetation from Lacustrine and marine Sediments (Ca. 3.40Ma). Org. Geochem. 38, 1607-1624. doi:10.1016/ j.orggeochem.2007.06.008

Feakins, S. J., Levin, N. E., Liddy, H. M., Sieracki, A., Eglinton, T. I., and Bonnefille, R. (2013). Northeast African Vegetation Change over 12 m.Y. Geology 41, 295-298. doi:10.1130/g33845.1 
Ferraro, J. V., Plummer, T. W., Pobiner, B. L., Oliver, J. S., Bishop, L. C., Braun, D. R., et al. (2013). Earliest Archaeological Evidence of Persistent Hominin Carnivory. PLOS One 8 (e62174), e62174-10. doi:10.1371/ journal.pone.0062174

Ferring, R., Oms, O., Agusti, J., Berna, F., Nioradze, M., Shelia, T., et al. (2011). Earliest Human Occupations at Dmanisi (Georgian Caucasus) Dated to 1.851.78 Ma. Proc. Natl. Acad. Sci. 108 (26), 10432-10436. doi:10.1073/ pnas. 1106638108

Figueirido, B., Palmqvist, P., Pérez-Claros, J. A., and Janis, C. M. (2019). Sixty-six Million Years along the Road of Mammalian Ecomorphological Specialization. Proc. Natl. Acad. Sci. USA 116 (26), 12698-12703. doi:10.1073/ pnas. 1821825116

Fjeldså, J., and Lovett, J. C. (1997). Geographical Patterns of Old and Young Species in African forest Biota: the Significance of Specific Montane Areas as Evolutionary Centres. Biodiversity \& Conservation 6, 325-346.

Foley, R. (1995). Humans before Humanity. Oxford: Wiley-Blackwell.

F. White (Editor) (1983). The Vegetation of Africa: A Descriptive Memoir to Accompany the UNESCO/AETFAT/UNSO Vegetation Map of Africa (Paris: Unesco).

Gabunia, L., Vekua, A., Lordkipanidze, D., Swisher, C. C., Ferring, R., Justus, A., et al. (2000). Earliest Pleistocene Hominid Cranial Remains from Dmanisi, Republic of Georgia: Taxonomy, Geological Setting, and Age. Science 288 (5468), 1019-1025. doi:10.1126/science.288.5468.1019

Garcia, T., Féraud, G., Falguères, C., de Lumley, H., Perrenoud, C., and Lordkipanidze, D. (2010). Earliest Human Remains in Eurasia: New 40Ar/ 39Ar Dating of the Dmanisi Hominid-Bearing Levels, Georgia. Quat. Geochronol. 5 (4), 443-451. doi:10.1016/j.quageo.2009.09.012

Geldenhuys, C. J. (1992). Richness, Composition and Relationships of the Floras of Selected Forests in Southern Africa. Bothalia 22, 205-233. doi:10.4102/ abc.v22i2.847

Glikson, A. (2013). Fire and Human Evolution: The Deep-Time Blueprints of the Anthropocene. Anthropocene 3, 89-92. doi:10.1016/j.ancene.2014.02.002

Godwin, H. (1934). Pollen Analysis. An Outline of the Problems and Potentialities of the Method. Part Ii. General Applications of Pollen Analysis. New Phytol. 33 (5), 325-358. doi:10.1111/j.1469-8137.1934.tb06819.x

Gowlett, J. A. J. (2016). The Discovery of Fire by Humans: a Long and Convoluted Process. Phil. Trans. R. Soc. B 371 (1696), 20150164. doi:10.1098/rstb.2015.0164

Groucutt, H. S. (2020). Volcanism and Human Prehistory in Arabia. J. Volcanology Geothermal Res. 402, 107003. doi:10.1016/j.jvolgeores.2020.107003

Hamilton, R., Penny, D., and Hall, T. L. (2020). Forest, Fire \& Monsoon: Investigating the Long-Term Threshold Dynamics of South-East Asia's Seasonally Dry Tropical Forests. Quat. Sci. Rev. 238, 106334. doi:10.1016/ j.quascirev.2020.106334

Hardt, T., Menke, P. R., and Hardt, B. (2015). "Paleoecology: An Adequate Window on the Past? Handbook of Paleoanthropology. Editors W. Henke and I. Tattersall. 2nd ed (Berlin: Springer-Verlag), 571-622. doi:10.1007/978-3642-39979-4_17

Harmand, S., Lewis, J. E., Feibel, C. S., Lepre, C. J., Prat, S., Lenoble, A., et al. (2015). 3.3-million-year-old Stone Tools from Lomekwi 3, West Turkana, Kenya. Nature 521, 310-315. doi:10.1038/nature14464

Harrison, T. (2002). The First Record of Fossil Hominins from the Ndolanya Beds, Laetoli, Tanzania. Am. J. Phys. Anthropol. 117, 83. doi:10.1002/ajpa.20012

Haws, J. A. (2012). Paleolithic Socionatural Relationships during MIS 3 and 2 in central Portugal. Quat. Int. 264, 61-77. doi:10.1016/j.quaint.2011.10.003

Hay, R. (1976). Geology of the Olduvai Gorge: A Study of Sedimentation in a Semiarid Basin. London, England: University of California Press.

Henry, A. G., Ungar, P. S., Passey, B. H., Sponheimer, M., Rossouw, L., Bamford, M., et al. (2012). The Diet of Australopithecus Sediba. Nature 487, 90-93. doi:10.1038/nature11185

Herries, A. I. R., Martin, J. M., Leece, A. B., Adams, J. W., Boschian, G., JoannesBoyau, R., et al. (2020). Contemporaneity of Australopithecus, Paranthropus, and Early Homo Erectus in South Africa. Science 368 (6486), eaaw7293. doi:10.1126/science.aaw7293

Hirota, M., Holmgren, M., Van Nes, E. H., and Scheffer, M. (2011). Global Resilience of Tropical Forest and Savanna to Critical Transitions. Science 334 (6053), 232-235. doi:10.1126/science.1210657

Holling, C. S. (1973). Resilience and Stability of Ecological Systems. Annu. Rev. Ecol. Syst. 4 (1), 1-23. doi:10.1146/annurev.es.04.110173.000245
Itambu, M. (2019).Diversity of Plant Niches Available for Hominin Settlement during Upper Bed I-Lower Bed II: A Phytolith Perspective, Oldupai Gorge (Tanzania). Calgary, Canada: University of Calgary. PhD in Archaeology.

Joannes-Boyau, R., Adams, J. W., Austin, C., Arora, M., Moffat, I., Herries, A. I. R., et al. (2019). Elemental Signatures of Australopithecus Africanus Teeth Reveal Seasonal Dietary Stress. Nature 572 (7767), 112-115. doi:10.1038/s41586-0191370-5

Johanson, D. C., Lovejoy, C. O., Kimbel, W. H., White, T. D., Ward, S. C., Bush, M. E., et al. (1982). Morphology of the Pliocene Partial Hominid Skeleton (A.L. 288-1) from the Hadar Formation, Ethiopia. Am. J. Phys. Anthropol. 57, 403-451. doi:10.1002/ajpa.1330570403

Kaboth-Bahr, S., Gosling, W. D., Vogelsang, R., Bahr, A., Scerri, E. M. L., Asrat, A., et al. (2021). Paleo-ENSO Influence on African Environments and Early Modern Humans. Proc. Natl. Acad. Sci. USA 118 (23), e2018277118. doi:10.1073/pnas.2018277118

King, G., and Bailey, G. (2006). Tectonics and Human Evolution. Antiquity 80 (308), 265-286. doi:10.1017/S0003598X00093613

Kovarovic, K., Slepkov, R., and McNulty, K. P. (2013). Ecological Continuity between Lower and Upper Bed II, Olduvai Gorge, Tanzania. J. Hum. Evol. 64, 538-555. doi:10.1016/j.jhevol.2013.02.010

Laporte, L. F., and Zihlman, A. (1983). Plates, Climate and Hominoid Evolution. South Afr. J. Sci. 79, 96-110.

Leakey, L. S. B. (1959). A New Fossil Skull from Olduvai. Nature 184, 491-493. doi:10.1038/184491a0

Leakey, M. D. (1971). "Olduvai Gorge," in Excavations in Beds I and II, 1960 - 1963 (Cambridge: Cambridge University Press), Vol. 3.

Leakey, M. G., Feibel, C. S., McDougall, I., and Walker, A. (1995). New FourMillion-Year-Old Hominid Species from Kanapoi and Allia Bay, Kenya. Nature 376, 565-571. doi:10.1038/376565a0

Ledogar, J. A., Smith, A. L., Benazzi, S., Weber, G. W., Spencer, M. A., Carlson, K. B., et al. (2016). Mechanical Evidence that Australopithecus Sediba Was Limited in its Ability to Eat Hard Foods. Nat. Commun. 7 (1), 10596. doi:10.1038/ncomms10596

Lemorini, C., Bishop, L. C., Plummer, T. W., Braun, D. R., Ditchfield, P. W., and Oliver, J. S. (2019). Old Stones' Song-Second Verse: Use-Wear Analysis of Rhyolite and Fenetized Andesite Artifacts from the Oldowan Lithic Industry of Kanjera South, Kenya. Archaeol Anthropol. Sci. 11 (9), 4729-4754. doi:10.1007/ s12520-019-00800-z

Lemorini, C., Plummer, T. W., Braun, D. R., Crittenden, A. N., Ditchfield, P. W., Bishop, L. C., et al. (2014). Old Stones' Song: Use-Wear Experiments and Analysis of the Oldowan Quartz and Quartzite Assemblage from Kanjera South (Kenya). J. Hum. Evol. 72, 10-25. doi:10.1016/ j.jhevol.2014.03.002

Levin, N. E., Quade, J., Simpson, S., Semaw, S., and Rogers, M. (2004). Isotopic Evidence for Plio-Pleistocene Environmental Change at Gona, Ethiopia. Earth Planet. Sci. Lett. 219 (1-2), 93-110. doi:10.1016/s0012-821x(03)00707-6

Levin, N. E., Simpson, S. W., Quade, J., Cerling, T. E., and Frost, S. R. (2008). Herbivore Enamel Carbon Isotopic Composition and the Environmental Context of Ardipithecus at Gona, Ethiopia. Geol. Soc. America Spec. Paper 446, 215-234. doi:10.1130/2008.2446(10)

Levin, N. E., Brown, F. H., Behrensmeyer, A. K., Bobe, R., and Cerling, T. E. (2011). Paleosol Carbonates from the Omo Group: Isotopic Records of Local and Regional Environmental Change in East Africa. Palaeogeogr. Palaeoclimatol. Palaeoecol. 307, 75-89. doi:10.1016/j.palaeo.2011.04.026

L. Mucina and M. Rutherford (Editors) (2006). The Vegetation of South Africa, Lesotho, and Swaziland (Pretoria: Sanbi).

Lovejoy, O., Suwa, G., Simpson, S., Matternes, J. H., and White, T. D. (2009). The Great Divides: Ardipithecus Ramidus Reveals the Postcrania of Our Last Common Ancestors with African Apes. Science 326, 100-106. doi:10.1126/ science. 1175833

Lupien, R. L., Russell, J. M., Feibel, C., Beck, C., Castañeda, I., Deino, A., et al. (2018). A Leaf Wax Biomarker Record of Early Pleistocene Hydroclimate from West Turkana, Kenya. Quat. Sci. Rev. 186, 225-235. doi:10.1016/ j.quascirev.2018.03.012

Lupien, R. L., Russell, J. M., Grove, M., Beck, C. C., Feibel, C. S., and Cohen, A. S. (2020). Abrupt Climate Change and its Influences on Hominin Evolution during the Early Pleistocene in the Turkana Basin, Kenya. Quat. Sci. Rev. 245, 106531. doi:10.1016/j.quascirev.2020.106531 
Lupien, R. L., Russell, J. M., Subramanian, A., Kinyanjui, R., Beverly, E. J., Uno, K. T., et al. (2021). Eastern African Environmental Variation and its Role in the Evolution and Cultural Change of Homo over the Last 1 Million Years. J. Hum. Evol. 157, 103028. doi:10.1016/j.jhevol.2021.103028

Lupien, R. L., Russell, J. M., Yost, C. L., Kingston, J. D., Deino, A. L., Logan, J., et al. (2021). Vegetation Change in the Baringo Basin, East Africa across the Onset of Northern Hemisphere Glaciation 3.3-2.6 Ma. Palaeogeogr. Palaeoclimatol. Palaeoecol. 570, 109426. doi:10.1016/j.palaeo.2019.109426

Magill, C. R., Ashley, G. M., Domínguez-Rodrigo, M., and Freeman, K. H. (2015). Dietary Options and Behavior Suggested by Plant Biomarker Evidence in an Early Human Habitat. Proc. Natl. Acad. Sci. U S A. 113 (11), 2874-2879. doi:10.1073/pnas.1507055113

Magill, C. R., Ashley, G. M., and Freeman, K. H. (2013a). Ecosystem Variability and Early Human Habitats in Eastern Africa. Proc. Natl. Acad. Sci. USA 110 (4), 1167-1174. doi:10.1073/pnas.1206276110

Magill, C. R., Ashley, G. M., and Freeman, K. H. (2013b). Water, Plants, and Early Human Habitats in Eastern Africa. Proc. Natl. Acad. Sci. USA 110 (4), 1175-1180. doi:10.1073/pnas.1209405109

Malhi, Y., Wright, J., Malhi, Y., and Wright, J. (2004). Spatial Patterns and Recent Trends in the Climate of Tropical Rainforest Regions. Phil. Trans. R. Soc. Lond. B 359 (1443), 311-329. doi:10.1098/rstb.2003.1433

Marean, C. W., Anderson, R. J., Bar-Matthews, M., Braun, K., Cawthra, H. C., Cowling, R. M., et al. (2015). A New Research Strategy for Integrating Studies of Paleoclimate, Paleoenvironment, and Paleoanthropology. Evol. Anthropol. 24 (2), 62-72. doi:10.1002/evan.21443

Martin, J. M., Leece, A. B., Neubauer, S., Baker, S. E., Mongle, C. S., Boschian, G., et al. (2021). Drimolen Cranium DNH 155 Documents Microevolution in an Early Hominin Species. Nat. Ecol. Evol. 5 (1), 38-45. doi:10.1038/s41559-02001319-6

Maslin, M. A., Brierley, C. M., Milner, A. M., Shultz, S., Trauth, M. H., and Wilson, K. E. (2014). East African Climate Pulses and Early Human Evolution. Quat. Sci. Rev. 101, 1-17. doi:10.1016/j.quascirev.2014.06.012

Maslin, M. A., Christensen, B., and Wilson, K. E. (2013). "Tectonics, Orbital Forcing, Global Climate Change, and Human Evolution in Africa," in Early Hominin Paleoecology. Editors M. Sponheimer, J. A. Lee-Thorp, K. E. Reed, and P. Ungar (Boulder, CO: University of Colorado Press), 103-160. doi:10.5876/ 9781607322252:c04

Maslin, M. A., Shultz, S., and Trauth, M. H. (2015). A Synthesis of the Theories and Concepts of Early Human Evolution. Phil. Trans. R. Soc. B 370, 20140064. doi:10.1098/rstb.2014.0064

Maslin, M. A., and Trauth, M. H. (2009). "Plio-Pleistocene East African Pulsed Climate Variability and its Influence on Early Human Evolution," in The First Humans - Origin and Early Evolution of the Genus Homo. Editors F. E. Grine, J. G. Fleagle, and R. E. Leakey (Netherlands: Springer), 151-158. doi:10.1007/ 978-1-4020-9980-9_13

McCain, C. M., and King, S. R. B. (2014). Body Size and Activity Times Mediate Mammalian Responses to Climate Change. Glob. Change Biol. 20 (6), 1760-1769. doi:10.1111/gcb.12499

Mercader, J., Akuku, P., Boivin, N., Bugumba, R., Bushozi, P., Camacho, A., et al. (2021). Earliest Olduvai Hominins Exploited Unstable Environments 2 Million Years Ago. Nat. Commun. 12 (1), 3. doi:10.1038/s41467-020-20176-2

Morrison, M. E. S., and Hamilton, A. C. (1974). Vegetation and Climate in the Uplands of South-Western Uganda during the Later Pleistocene Period: II. Forest Clearance and Other Vegetational Changes in the Rukiga Highlands during the Past 8000 Years. J. Ecol. 62 (1), 1-31. doi:10.2307/2258877

Nash, D. J., De Cort, G., Chase, B. M., Verschuren, D., Nicholson, S. E., Shanahan, T. M., et al. (2016). African Hydroclimatic Variability during the Last 2000 Years. Quat. Sci. Rev. 154, 1-22. doi:10.1016/j.quascirev.2016.10.012

Nicholson, S. E. (1996). "A Review of Climate Dynamics and Climate Variability in Eastern Africa," in The Limnology, Climatology, and Paleoclimatology of the East African Rift Lakes. Editors T. C. Johnson and E. O. Odada (Amsterdam: Gordon \& Breach), 25-56.

Nicholson, S. E. (1993). An Overview of African Rainfall Fluctuations of the Last Decade. J. Clim. 6 (7), 1463-1466. doi:10.1175/1520-0442(1993)006<1463: aooarf $>2.0 . \operatorname{co} ; 2$

Nicholson, S. E., and Selato, J. C. (2000). The Influence of La Nina on African Rainfall. Int. J. Climatol. 20 (14), 1761-1776. doi:10.1002/1097-0088(20001130) 20::14<1761:aid-joc580>3.0.co;2-w
Nicholson, S. (2016). The Turkana Low-level Jet: Mean Climatology and Association with Regional Aridity. Int. J. Climatol. 36 (6), 2598-2614. doi:10.1002/joc.4515

Olson, D. M., Dinerstein, E., Wikramanayake, E. D., Burgess, N. D., Powell, G. V. N., Underwood, E. C., et al. (2001). Terrestrial Ecoregions of the World: A New Map of Life on Earth. BioScience 51 (11), 933-938. doi:10.1641/00063568(2001)05110.1641/0006-3568(2001)051[0933:teotwa]2.0.co;2

Owen, R. B., Muiruri, V. M., Lowenstein, T. K., Renaut, R. W., Rabideaux, N., Luo, S., et al. (2018). Progressive Aridification in East Africa over the Last Half Million Years and Implications for Human Evolution. Proc. Natl. Acad. Sci. USA 115 (44), 11174-11179. doi:10.1073/pnas.1801357115

Pante, M. C., and de la Torre, I. (2018). A Hidden Treasure of the Lower Pleistocene at Olduvai Gorge, Tanzania: The Leakey HWK EE Assemblage. J. Hum. Evol. 120, 114-139. doi:10.1016/j.jhevol.2017.06.006

Parhi, P., Giannini, A., Gentine, P., and Lall, U. (2016). Resolving Contrasting Regional Rainfall Responses to El Niño over Tropical Africa. J. Clim. 29 (4), 1461-1476. doi:10.1175/JCLI-D-15-0071.1

Parmentier, I., Malhi, Y., Senterre, B., Whittaker, R. J., Alonso, A., Balinga, M. P. B., et al. (2007). The Odd Man Out? Might Climate Explain the Lower Tree ?-diversity of African Rain Forests Relative to Amazonian Rain Forests? J. Ecol. 95 (5), 1058-1071. doi:10.1111/j.1365-2745.2007.01273.x

Patalano, R., Roberts, P., Boivin, N., Petraglia, M. D., and Mercader, J. (2021). Plant Wax Biomarkers in Human Evolutionary Studies. Evol. Anthropol. Issues News Rev. n/a(n/a). doi:10.1002/evan10.1002/evan.21921

Patalano, R. (2019) The Environmental Context of the Earliest Acheulean at Olduvai Gorge, Tanzania. Calgary, Canada: University of Calgary.

Pausata, F. S. R., Zhang, Q., Muschitiello, F., Lu, Z., Chafik, L., Niedermeyer, E. M., et al. (2017). Greening of the Sahara Suppressed ENSO Activity during the Midholocene. Nat. Commun. 8 (1), 16020. doi:10.1038/ncomms 16020

Pennington, R. T., Lavin, M., and Oliveira-Filho, A. (2009). Woody Plant Diversity, Evolution, and Ecology in the Tropics: Perspectives from Seasonally Dry Tropical Forests. Annu. Rev. Ecol. Evol. Syst. 40 (1), 437-457. doi:10.1146/ annurev.ecolsys.110308.120327

Petraglia, M. (2017). "Hominins on the Move: An Assessment of Anthropogenic Shaping of Environments in the Palaeolithic," in Human Dispersal and Species Movement: From Prehistory to the Present. Editors M. Petraglia, N. Boivin, and R. Crassard (Cambridge: Cambridge University Press), 90-118.

Pickford, M., and Senut, B. (2001). The Geological and Faunal Context of Late Miocene Hominid Remains from Lukeino, Kenya. Comptes Rendus de l'Académie des Sci. - Ser. IIA - Earth Planet. Sci. 332, 145-152. doi:10.1016/ s1251-8050(01)01528-2

Piperno, D. R. (2006). Phytoliths: A Comprehensive Guide for Archaeologists and Paleoecologists. Oxford: AltaMira Press.

Plummer, T. W., Ditchfield, P. W., Bishop, L. C., Kingston, J. D., Ferraro, J. V., Braun, D. R., et al. (2009). Oldest Evidence of Tool Making Hominins in a Grassland-Dominated Ecosystem. PLOS One 4 (9), e7199-8. doi:10.1371/ journal.pone.0007199

Plummer, T. W., and Finestone, E. M. (2018). "Archeological Sites from 2.6-2.0 Ma: Toward a Deeper Understanding of the Early Oldowan," in Rethinking Human Evolution. Editors J. H. Schwartz (Cambridge, USA: The MIT Press).

Pontzer, H. (2012). Ecological Energetics in Early Homo. Curr. Anthropol. 53 (S6), S346-S358. doi:10.1086/667402

Potts, R., Dommain, R., Moerman, J. W., Behrensmeyer, A. K., Deino, A. L., Riedl, S., et al. (2020). Increased Ecological Resource Variability during a Critical Transition in Hominin Evolution. Sci. Adv. 6 (43), eabc8975. doi:10.1126/ sciadv.abc 8975

Potts, R. (1998a). Environmental Hypotheses of Hominin Evolution. Am. J. Phys. Anthropol. 107, 93-136. doi:10.1002/(sici)1096-8644(1998)107:27+<93::aidajpa5 $>3.0 . c 0 ; 2-\mathrm{x}$

Potts, R. (1996). Evolution and Climate Variability. Science 273, 922-923. doi:10.1126/science.273.5277.922

Potts, R. (2013). Hominin Evolution in Settings of strong Environmental Variability. Quat. Sci. Rev. 73, 1-13. doi:10.1016/j.quascirev.2013.04.003

Potts, R. (1998b). Variability Selection in Hominid Evolution. Evol. Anthropol. 7 (3), 81-96. doi:10.1002/(sici)1520-6505(1998)7:3<81:aid-evan3>3.0.co;2-a

Prassack, K. A. (2010). Late Pliocene Avifauna from the Hominid-Bearing Zinjanthropus Land Surface at Olduvai Gorge, Tanzania. In Proceedings of the VII International Meeting of the Society of Avian Paleontology and 
Evolution, Ed. W.E. Boles and T.H. Worthy. Rec. Aust. Mus. 62, 185-192. doi:10.3853/j.0067-1975.62.2010.1541

Prassack, K. A., Pante, M. C., Njau, J. K., and de la Torre, I. (2018). The Paleoecology of Pleistocene Birds from Middle Bed II, at Olduvai Gorge, Tanzania, and the Environmental Context of the Oldowan-Acheulean Transition. J. Hum. Evol. 120, 32-47. doi:10.1016/j.jhevol.2017.11.003

Püschel, H. P., Bertrand, O. C., O’Reilly, J. E., Bobe, R., and Püschel, T. A. (2021). Divergence-time Estimates for Hominins Provide Insight into Encephalization and Body Mass Trends in Human Evolution. Nat. Ecol. Evol. 5 (6), 808-819. doi:10.1038/s41559-021-01431-1

Quade, J., and Levin, N. E. (2013). "East African Hominin Paleoecology: Isotopic Evidence from Paleosols," in Early Hominin Paleoecology. Editors M. Sponheimer, J. A. Lee-Thorp, K. E. Reed, and P. Ungar (Boulder, CO: University Press of Colorado), 59-102. doi:10.5876/9781607322252:c03

Quinn, R. L., Lepre, C. J., Feibel, C. S., Wright, J. D., Mortlock, R. A., Harmand, S., et al. (2013). Pedogenic Carbonate Stable Isotopic Evidence for Wooded Habitat Preference of Early Pleistocene Tool Makers in the Turkana Basin. J. Hum. Evol. 65 (1), 65-78. doi:10.1016/j.jhevol.2013.04.002

Ravelo, A. C., Andreasen, D. H., Lyle, M., Olivarez Lyle, A., and Wara, M. W. (2004). Regional Climate Shifts Caused by Gradual Global Cooling in the Pliocene Epoch. Nature 429, 263-267. doi:10.1038/nature02567

Rayner, R. J., Moon, B. P., and Masters, J. C. (1993). The Makapansgat Australopithecine Environment. J. Hum. Evol. 24, 219-231. doi:10.1006/ jhev.1993.1016

Reynolds, S. C., Wilkinson, D. M., Marston, C. G., and O'Regan, H. J. (2015). The 'mosaic Habitat' Concept in Human Evolution: Past and Present. Trans. R. Soc. South Africa 70 (1), 57-69. doi:10.1080/0035919X.2015.1007490

Roberts, P., Prendergast, M. E., Janzen, A., Shipton, C., Blinkhorn, J., Zech, J., et al. (2020). Late Pleistocene to Holocene Human Palaeoecology in the Tropical Environments of Coastal Eastern Africa. Palaeogeogr. Palaeoclimatol. Palaeoecol. 537, 109438. doi:10.1016/j.palaeo.2019.109438

Rossouw, L., and Scott, L. (2011). "Phytoliths and Pollen, the Microscopic Plant Remains in Pliocene Volcanic Sediments Around Laetoli, Tanzania," in Paleontology and Geology of Laetoli: Human Evolution in Context. Editor T. Harrison (Springer Science \& Business Media), 201-215. doi:10.1007/ 978-90-481-9956-3_9

Sachse, D., Billault, I., Bowen, G. J., Chikaraishi, Y., Dawson, T. E., Feakins, S. J., et al. (2012). Molecular Paleohydrology: Interpreting the Hydrogen-Isotopic Composition of Lipid Biomarkers from Photosynthesizing Organisms. Annu. Rev. Earth Planet. Sci. 40, 221-249. doi:10.1146/annurev-earth-042711-105535

Sanders, W. J. (2020). Proboscidea from Kanapoi, Kenya. J. Hum. Evol. 140, 102547. doi:10.1016/j.jhevol.2018.10.013

Saylor, B. Z., Gibert, L., Deino, A., Alene, M., Levin, N. E., Melillo, S. M., et al. (2019). Age and Context of Mid-pliocene Hominin Cranium from WoransoMille, Ethiopia. Nature 573 (7773), 220-224. doi:10.1038/s41586-019-1514-7

Schaebitz, F., Asrat, A., Lamb, H. F., Cohen, A. S., Foerster, V., Duesing, W., et al. (2021). Hydroclimate Changes in Eastern Africa over the Past 200,000 Years May Have Influenced Early Human Dispersal. Commun. Earth Environ. 2 (1), 123. doi:10.1038/s43247-021-00195-7

Scherjon, F., Bakels, C., MacDonald, K., and Roebroeks, W. (2015). Burning the Land. Curr. Anthropol. 56 (3), 299-326. doi:10.1086/681561

Seddon, A. W. R. (2021). Special Feature: Measuring Components of Ecological Resilience in Long-Term Ecological Datasets. Biol. Lett. 17(1), 20200881doi:10.1098/rsbl.2020.0881

Semaw, S., Renne, P., Harris, J. W. K., Feibel, C. S., Bernor, R. L., Fesseha, N., et al. (1997). 2.5-million-year-old Stone Tools from Gona, Ethiopia. Nature 385, 333-336. doi:10.1038/385333a0

Semaw, S., Rogers, M. J., Quade, J., Renne, P. R., Butler, R. F., Dominguez-Rodrigo, M., et al. (2003). 2.6-Million-year-old Stone Tools and Associated Bones from OGS-6 and OGS-7, Gona, Afar, Ethiopia. J. Hum. Evol. 45, 169-177. doi:10.1016/s0047-2484(03)00093-9

Sept, J. M. (2013). in Plants and Protopeople: Paleobotanical Reconstruction and Early Hominin EcologyEarly Hominin Paleoecology. Editors M. Sponheimer, J. A. Lee-Thorp, K. E. Reed, and P. Ungar (Boulder, CO: University Press of Colorado).

Sepulchre, P., Ramstein, G., Fluteau, F., Schuster, M., Tiercelin, J.-J., and Brunet, M. (2006). Tectonic Uplift and Eastern Africa Aridification. Science 313, 1419-1423. doi:10.1126/science.1129158
Sikes, N. E. (1994). Early Hominid Habitat Preferences in East Africa: Paleosol Carbon Isotopic Evidence. J. Hum. Evol. 27, 25-45. doi:10.1006/jhev.1994.1034

Sintayehu, D. W. (2018). Impact of Climate Change on Biodiversity and Associated Key Ecosystem Services in Africa: a Systematic Review. Ecosystem Health and Sustainability 4 (9), 225-239. doi:10.1080/20964129.2018.1530054

Sloggett, G. C. (2016). The Plio-Pleistocene Paleoecology of Makapansgat: A Site Overview and Review of Paleoecological Reconstructions from the Time of Australopithecus Africanus. vis-à-vis: Explorations Anthropol. 13 (1), 54-77.

Sponheimer, M., Passey, B. H., de Ruiter, D. J., Guatelli-Steinberg, D., Cerling, T. E., and Lee-Thorp, J. A. (2006). Isotopic Evidence for Dietary Variability in the Early Hominin Paranthropus Robustus. Science 314, 980-982. doi:10.1126/ science. 1133827

Stanistreet, I. G., McHenry, L. J., Stollhofen, H., and de la Torre, I. (2018). Bed II Sequence Stratigraphic Context of EF-HR and HWK EE Archaeological Sites, and the Oldowan/Acheulean Succession at Olduvai Gorge, Tanzania. J. Hum. Evol. 120, 19-31. doi:10.1016/j.jhevol.2018.01.005

Stern, N., Bunn, H. T., Kroll, E. M., Haynes, G., McBrearty, S., Sept, J., et al. (1993). The Structure of the Lower Pleistocene Archaeological Record: A Case Study from the Koobi Fora Formation [and Comments and Reply]. Curr. Anthropol. 34, 201-225. doi:10.1086/204164

Stewart, J. R., Lister, A. M., Barnes, I., and Dalén, L. (2010). Refugia Revisited: Individualistic Responses of Species in Space and Time. Proc. R. Soc. B. 277, 661-671. doi:10.1098/rspb.2009.1272

Stewart, M., Carleton, W. C., and Groucutt, H. S. (2021). Climate Change, Not Human Population Growth, Correlates with Late Quaternary Megafauna Declines in North America. Nat. Commun. 12 (1), 965. doi:10.1038/s41467021-21201-8

Stollhofen, H., Stanistreet, I. G., Toth, N., Schick, K. D., Rodríguez-Cintas, A., Albert, R. M., et al. (2021). Olduvai's Oldest Oldowan. J. Hum. Evol. 150, 102910. doi:10.1016/j.jhevol.2020.102910

Strotz, L. C., Simões, M., Girard, M. G., Breitkreuz, L., Kimmig, J., and Lieberman, B. S. (2018). Getting Somewhere with the Red Queen: Chasing a Biologically Modern Definition of the Hypothesis. Biol. Lett. 14 (5), 20170734. doi:10.1098/ rsbl.2017.0734

Thompson, J. C., Wright, D. K., Ivory, S. J., Choi, J.-H., Nightingale, S., Mackay, A., et al. (2021). Early Human Impacts and Ecosystem Reorganization in Southerncentral Africa. Sci. Adv. 7 (19), eabf9776. doi:10.1126/sciadv.abf 9776

Tierney, J. E., deMenocal, P. B., and Zander, P. D. (2017). A Climatic Context for the Out-Of-Africa Migration. Geology 45 (11), 1023-1026. doi:10.1130/ g39457.1

Trauth, M. H., Asrat, A., Berner, N., Bibi, F., Foerster, V., Grove, M., et al. (2021). Northern Hemisphere Glaciation, African Climate and Human Evolution. Quat. Sci. Rev. 268, 107095. doi:10.1016/j.quascirev.2021.107095

Trauth, M. H., Maslin, M. A., Deino, A. L., Junginger, A., Lesoloyia, M., Odada, E. O., et al. (2010). Human Evolution in a Variable Environment: the Amplifier Lakes of Eastern Africa. Quat. Sci. Rev. 29, 2981-2988. doi:10.1016/ j.quascirev.2010.07.007

Trauth, M. H., Maslin, M. A., Deino, A., and Strecker, M. R. (2005). Late Cenozoic Moisture History of East Africa. Science 309, 2051-2053. doi:10.1126/ science.1112964

Ummenhofer, C. C., Kulüke, M., and Tierney, J. E. (2018). Extremes in East African Hydroclimate and Links to Indo-Pacific Variability on Interannual to Decadal Timescales. Clim. Dyn. 50 (7), 2971-2991. doi:10.1007/s00382-017-3786-7

Uno, K. T., Polissar, P. J., Kahle, E., Feibel, C., Harmand, S., Roche, H., et al. (2016b). A Pleistocene Palaeovegetation Record from Plant Wax Biomarkers from the Nachukui Formation, West Turkana, Kenya. Philos. Trans. R. Soc. Lond. B Biol. Sci. 371 (20150235), 1-10. doi:10.1098/rstb.2015.0235

Uno, K. T., Polissar, P. J., Jackson, K. E., and deMenocal, P. B. (2016a). Neogene Biomarker Record of Vegetation Change in Eastern Africa. Proc. Natl. Acad. Sci. USA 113 (23), 6355-6363. doi:10.1073/pnas.1521267113

Uribelarrea, D., Domínguez-Rodrigo, M., Pérez-González, A., Vegas Salamanca, J., Baquedano, E., Mabulla, A., et al. (2014). Geo-archaeological and Geometrically Corrected Reconstruction of the 1.84 Ma FLK Zinj Paleolandscape at Olduvai Gorge, Tanzania. Quat. Int. 322-323, 7-31. doi:10.1016/j.quaint.2013.12.023

Uribelarrea, D., Martín-Perea, D., Díez-Martín, F., Sánchez-Yustos, P., Domínguez-Rodrigo, M., Baquedano, E., et al. (2017). A Reconstruction of the Paleolandscape during the Earliest Acheulian of FLK West: The Coexistence of Oldowan and Acheulian Industries during Lowermost Bed II 
(Olduvai Gorge, Tanzania). Palaeogeogr. Palaeoclimatol. Palaeoecol. 488, 50-58. doi:10.1016/j.palaeo.2017.04.014

Van Valen, L. (1973). A New Evolutionary Law. Evol. Theor. 1, 1-30.

Van Wyk, A., and Smith, G. (2001). Regions of Floristic Endemism in Southern Africa. Cape Town: CTP Book Printers.

Villmoare, B., Kimbel, W. H., Seyoum, C., Campisano, C. J., DiMaggio, E. N., Rowan, J., et al. (2015). Early Homo at 2.8 Ma from Ledi-Geraru, Afar, Ethiopia. Science 347 (6228), 1352-1355. doi:10.1126/science.aaa1343

Vrba, E. S., Denton, G. H., and Prentice, M. L. (1989). Climatic Influences on Early Hominid Behavior. Ossa 14, 127-156. doi:10.1007/bf01705126

Vrba, E. S. (1995b). "On the Connection between Paleoclimate and Evolution," in Paleoclimate and Evolution, with Emphasis on Human Origins. Editors E. S. Vrba, G. H. Denton, T. C. Partridge, and L. H. Burckle (New Haven, CT: Yale University Press), 24-45.

Vrba, E. S. (2007). "Role of Environmental Stimuli in Hominid Origins," in Handbook of Paleoanthropology. Editors W. Henke and I. Tattersall (New York, NY: Springer), 1462.

Vrba, E. S. (1995a). “The Fossil Record of African Antelopes (Mammalia, Bovidae) in Relation to Human Evolution and Paleoclimate," in Paleoclimate and Evolution, with Emphasis on Human Origins. Editors E. S. Vrba, G. H. Denton, T. C. Partridge, and L. H. Burckle (New Haven, CT: Yale University Press), 385-424.

Washburn, S. L. (1960). Tools and Human Evolution. Sci. Am. 203 (3), 63-75. doi:10.1038/scientificamerican0960-62

White, F. (1979). The Guineo-Congolian Region and its Relationships to Other Phytochoria. Bull. du Jardin botanique Natl. de Belg./Bull. van de Natl. Plantentuin van België 49, 11-55. doi:10.2307/3667815

White, S. (2013). Grass Páramo as hunter-gatherer Landscape. The Holocene 23 (6), 898-915. doi:10.1177/0959683612471987

White, T. D., Ambrose, S. H., Suwa, G., Su, D. F., DeGusta, D., Bernor, R. L., et al. (2009a). Macrovertebrate Paleontology and the Pliocene Habitat of Ardipithecus Ramidus. Science 326 (5949), 87-93. doi:10.1126/ science. 1175822

White, T. D., Asfaw, B., Beyene, Y., Haile-Selassie, Y., Lovejoy, C. O., Suwa, G., et al. (2009b). Ardipithecus Ramidus and the Paleobiology of Early Hominids. Science 326 (64), 75-86. doi:10.1126/science.1175802

Whittaker, R. H. (1960). Vegetation of the Siskiyou Mountains, Oregon and California. Ecol. Monogr. 30 (3), 279-338. doi:10.2307/1943563

Williams, A. P., Funk, C., Michaelsen, J., Rauscher, S. A., Robertson, I., Wils, T. H. G., et al. (2012). Recent Summer Precipitation Trends in the Greater Horn of Africa and the Emerging Role of Indian Ocean Sea Surface Temperature. Clim. Dyn. 39 (9), 2307-2328. doi:10.1007/s00382-011-1222-y

Willis, K. J., Bennett, K. D., Burrough, S. L., Macias-Fauria, M., and Tovar, C. (2013). Determining the Response of African Biota to Climate Change: Using the Past to Model the Future. Phil. Trans. R. Soc. B 368 (1625), 20120491. doi:10.1098/rstb.2012.0491
Wilson, E. O. (1979). On Human Nature. Cambridge, MA: Harvard University Press.

WoldeGabriel, G., Ambrose, S. H., Barboni, D., Bonnefille, R., Bremond, L., Currie, B., et al. (2009). The Geological, Isotopic, Botanical, Invertebrate, and Lower Vertebrate Surroundings of Ardipithecus Ramidus. Science 326, 65e1-5. doi:10.1126/science.1175817

WoldeGabriel, G., Haile-Selassie, Y., Renne, P. R., Hart, W. K., Ambrose, S. H., Asfaw, B., et al. (2001). Geology and Palaeontology of the Late Miocene Middle Awash valley, Afar Rift, Ethiopia. Nature 412, 175-178. doi:10.1038/35084058 WoldeGabriel, G., White, T. D., Suwa, G., Renne, P., de Heinzelin, J., Hart, W. K., et al. (1994). Ecological and Temporal Placement of Early Pliocene Hominids at Aramis, Ethiopia. Nature 371, 330-333. doi:10.1038/371330a0

Wolpoff, M. H. (1980). Paleoanthropology. Knopf. New York: McGraw-Hill.

Wynn, J. G. (2001). Paleosols, Stable Carbon Isotopes, and Paleoenvironments of Hominid Evolution in the Neogene Turkana Basin, Northern Kenya. Eugene, Oregon: University of Oregon.

Wynn, J. G. (2004). Influence of Plio-Pleistocene Aridification on Human Evolution: Evidence from Paleosols of the Turkana Basin, Kenya. Am. J. Phys. Anthropol. 123, 106-118. doi:10.1002/ajpa.10317

Yang, W., Seager, R., Cane, M. A., and Lyon, B. (2015). The Annual Cycle of East African Precipitation. J. Clim. 28 (6), 2385-2404. doi:10.1175/JCLI-D-1400484.1

Zhu, R. X., Potts, R., Pan, Y. X., Yao, H. T., Lü, L. Q., Zhao, X., et al. (2008). Early Evidence of the Genus Homo in East Asia. J. Hum. Evol. 55 (6), 1075-1085. doi:10.1016/j.jhevol.2008.08.005

Zhu, Z., Dennell, R., Huang, W., Wu, Y., Qiu, S., Yang, S., et al. (2018). Hominin Occupation of the Chinese Loess Plateau since about 2.1 Million Years Ago. Nature 559 (7715), 608-612. doi:10.1038/s41586-018-0299-4

Conflict of Interest: The authors declare that the research was conducted in the absence of any commercial or financial relationships that could be construed as a potential conflict of interest.

Publisher's Note: All claims expressed in this article are solely those of the authors and do not necessarily represent those of their affiliated organizations, or those of the publisher, the editors and the reviewers. Any product that may be evaluated in this article, or claim that may be made by its manufacturer, is not guaranteed or endorsed by the publisher.

Copyright (C) 2021 Patalano, Hamilton, Finestone, Amano, Heddell-Stevens, Itambu, Petraglia and Roberts. This is an open-access article distributed under the terms of the Creative Commons Attribution License (CC BY). The use, distribution or reproduction in other forums is permitted, provided the original author(s) and the copyright owner(s) are credited and that the original publication in this journal is cited, in accordance with accepted academic practice. No use, distribution or reproduction is permitted which does not comply with these terms. 